\title{
Pehlevî Dilinde Yaşayan En Eski Kahramanlık Anlatısı: Yâdgâr-i Zerîrân
}

\author{
Oğuzhan Özoğlu*
}

\section{$\ddot{O} z$}

Yâdgâr-i Zerîrân (Ayādgār ì Zarērān), Keyanî hükümdarı Viştasp'ın Zerdüştîliğe intisabı nedeniyle Hunlar ile Keyanîler arasında yaşanan savaşı konu edinmektedir. $\mathrm{Bu}$ eser, Pehlevi dilinde günümüze ulaşmış en eski kahramanlık anlatısıdır. Bir taziyename olan Yâdgâr-i Zerîrân'ın Partça bir metne dayandığı düşünülmektedir. Sasaniler döneminde başlayan derleme faaliyetleri esnasında Sasani Pehlevicesine çevrilmiştir; buna rağmen metinde, Partçanın izi görülmektedir. Yâdgâr-i Zerîrân'ın bir şiirden çevrilmiş olduğu düşüncesi ise daha fazla kanıt gerektirmektedir. Hudayiname/şehname türü eserlere ve özellikle Dakikî'nin Geştaspnâmesine ve Firdevsî'nin Şehnamesine ilham veren bu eserde, Zerdüşt'e hiç atıf yapılmaması ilgi çekicidir. 346 satır ve 114 bent şeklinde Mihrâbân Keyhüsrev’in yazmaları (MK Kodeksi) arasında günümüze ulaşan eserin, farklı dillerde birçok çevirisi bulunmaktadır. $\mathrm{Bu}$ makalede, Yâdgâr-i Zerîrân'ın tarihlendirilmesi tartışılmış, eser ve kahramanları tanıtılmış, eserin Pehleviceden çevirisi araştırmacılara sunulmuş ve diğer çeviriler ile karşılaştırma yapılmıştır. Bu karşılaştırma ile araştırmacıların, metindeki müphem ifadeleri nasıl yorumladığı gösterilmiştir. Makale, Türkiye'deki Sasani kültürü araştırmacılarına, Pehlevî dilindeki en eski kahramanlık anlatısını tanıtmayı amaçlamaktadır. Metinde geçen dini kavramlar ve semboller, Zerdüştîlik araştırmalarına katkı sağlamak amacıyla ayrıca değerlendirilmiştir.

Anahtar Kelimeler: Yâdgâr-i Zerîrân, Zerîr, Viştasp, Zerdüştîlik, Pehlevice

Yüksek Lisans Öğrencisi, Ankara Üniversitesi, Kelam Anabilim Dalı, ogz.oz.ankara@, gmail.com ORCID: 0000-0002-2840-9268 


\title{
The Earliest Surviving Narrative of Heroism in Pahlavi Language: Ayādgār ì Zarērān
}

\author{
Oğuzhan Özoğlu*
}

\begin{abstract}
"Memorial of Zarēr" (Ayādgār ̄ $\mathbf{1}$ Zarērān) describes the story of war between the Xiyōns and the Kayanids that began with King Vishtasp accepted an invitation by Zoroaster. This text is the earliest surviving narrative of heroism in Pahlavi language. Memorial of Zarēr, a "ta'azieh", is thought to be based on a Parthian text. It was translated into Sasanian Pahlavi during the compilation activities that started early Sasanian periods; however, the text indicates the traces of Parthian language. The idea that Ayādgār $\bar{l}$ Zarērān was translated from a poem requires more evidence. It is interesting that there is no reference to Zoroaster in this book which inspired into $x w a d \bar{a} y-n \bar{a} m a g / \bar{s} a \bar{h}-n \bar{a} m a$ type works and especially Daqīî̀'s Gushtâsp-nāma and Ferdowsī’s Šāh-nāma. This work, which has survived between the manuscripts of Mehrabān Kay-Khosrow (MK Codex) in the form of 346 lines and 114 verses, has many translations in different languages. In this article; the date of Yâdgâr-i Zerîrân was discussed, the works and its heroes were introduced, the Turkish translation of the Pahlavi text was presented to the researchers and it compared with the other translations. This comparison shows how researchers interpret ambiguous expressions in the text. This article aims to introduce the oldest heroic narrative in the Pahlavi language to the Sasanian culture researchers in Turkey. The religious concepts and symbols in the text have been evaluated in order to contribute to Zoroastrian studies.
\end{abstract}

Keywords: Ayādgār ī Zarērān, Zarēr, Vištāspa, Zoroaster, Pahlavi Language

Graduate Student, Ankara University, Department of Kalam, ogz.oz.ankara@gmail. com ORCID: 0000-0002-2840-9268 


\section{Giriş}

Sasaniler, kültürel birikimlerinin farkındalığı ve Yunan karşılaşmasının tesiriyle erken dönemlerde milli kaynaklarını derleme faaliyetine girişmiştir. Kendi uygarlıklarını ulusal tarih sayesinde okuyan İranlıların kültürel birikimi, Yunan kaynaklarında "orijinallik" bağlamında sorgulanmaktadır. Herodotos, İranlıların gelenek ve göreneklerinden dini inançlarına kadar birçok hususta farklı kültürleri mezcettiklerini düşünmektedir. Ona göre İranlılar, giyim kuşamı Medlerden, savaş gereçlerini Mısırlılardan, sosyal münasebetleri Yunanlılardan, dini inançlarını Asurlular ve Araplardan almışlardır. ${ }^{1}$ Herodotos'un iddiaları, Yunanlıların İran uygarlığına bakışını yansıtır. Zira kimi araştırmacılar, bilhassa dini inançlar bağlamında, İranlıları fazlaca muhafazakâr görmektedir. ${ }^{2}$ Zerdüştî klasiklerinden Dînkerd' in III. kitabının sonunda derleme faaliyetleri ve eser hakkında verilen bilgiye göre Dînkerd, Zerdüşt'ün ilk öğrencilerinden biri tarafından kaleme alınmış ve Viştasp/Goştasp Şah'ın emri ile kopyalanmıştır. Asıl nüsha "saray hazinesi/kütüphanesi" Ganj-i Şâhîgân'a, bir diğer nüsha ise "arşiv binas1" Diz-i Nibişt'e yerleştirilmiştir. İskender'in İran seferi sırasında Diz-i Nibişt'te yer alan metinler yakılırken Ganj-i Şâhîgân'da yer alan metinler Romalıların eline geçmiş ve İskender, bu metinleri Yunancaya tercüme ettirmiştir. ${ }^{3}$ Devamında da Sasaniler döneminde ve Arap-Fars karşılaşmasi/İslamlaşma sürecinde Dînkerd'i derleme faaliyetleri anlatılır ve özellikle IV. kitapta, Sasaniler döneminde Hindistan, Roma ve diğer bölgelerden temin edilen coğrafya, astronomi, tıp ve benzeri ilimlerin de dini metinler ile beraber derlendiği belirtilir. ${ }^{4}$ Bir diğer Zerdüştî klasiği olan Ardâvîrâfnâme'nin ana teması, İskender işgalinin yıkımı sonrasında dini inançları pekiştirme amacıyla gerçekleşen miraç hadisesidir ve eserin başında Dînkerd'in adı verilerek anlatılanlar, Sasanilerin genel kanaatleriyle uyumludur. ${ }^{5}$ Büyük Bundehişn'de İskender'in III. Darius'u (M.Ö. 336-330) öldürmesi hikâye edilir ve buna göre İskender, Zend metinlerini Roma'ya

Herodotos, Tarih, çev. Müntekim Ökmen (İstanbul: Türkiye İş Bankası Kültür Yayınlar1, 2012), 75-78.

Osman Karatay, Iran ile Turan (Ankara: Karam Yayınları, 2013), 114.

Joseph Peterson, ed., Dînkerd III, çev. Ratanshah E. Kohiyar (1999), b.(bölüm) 420.

Said Oryan, ed., Dînkerd IV, çev. Meryem Rızaî (Tahran: Neşr-i İlmî, 1393), b.17-19.

Ardâvîrâfnâme, çev. Nimet Yıldırım (İstanbul: Pinhan Yayıncılık, 2017), 83-84. 
göndermiş/kaçırmış, Avesta'yı yakmış ve İranşehr'i doksan küçük hükümdara pay etmiştir. ${ }^{6}$

İran klasiklerinde yer alan İskender'in işgaline dair anlatılar, İran ulusal tarihi ile pekiştirilir. İran ulusal tarihi; Pişdadîler, Keyanîler, Eşkanîler ve Sasanîler dönemini konu edinmektedir. Bu tarih anlayışına göre İranlıların dünya egemenliği iddiası taşıyan ilk hanedanı Pişdadîler, Keyûmers'ten Keykubâd'a kadar hüküm sürmüştür. Kaynaklar Keyûmers'i birbirlerinden farklı tanıtmaktadırlar. Kimi kaynaklara göre Keyûmers ilk insan, kimilerine göre ilk hükümdardır. Nitekim bu farklılık Arap-Fars etkileşiminin yoğun olduğu dönemde de sürecektir. Firdevsî (ö.411/1020), Şehnamesinde Keyûmers'i yeryüzündeki ilk hükümdar olarak işleyecek ve Sealibî (ö.429/1038) gibi Müslüman tarihçiler, onun ilk insan/Âdem olup olmad1ğını tartışacaktır. ${ }^{7} \mathrm{Bu}$ tartışma, ulusal tarihin işlevine işaret eder. Zira İran ulusal tarihi veya mit/efsane yazımı, Zerdüştî teo-ontolojik argümanların temelini oluşturur. Anlatılanların tarihi gerçekliklerini bir kenara bırakırsak gerek Sasaniler döneminde gerekse Arap-Fars karşılaşması/İslamlaşma sürecinde İranlıların, insanlık tarihini ve kültürünü kendi eksenlerinde yorumladıklarını söyleyebiliriz. Bu anlayışa göre dünyanın önde gelen medeniyetlerinin kaynă̆ İ́an medeniyetidir ve İranlıların ilk öğretmeni Zerdüşt'tür. "Öğretmen Zerdüşt" bilimden dine, sanata ve kültüre, her alanda çı̆̆ır açmış bir peygamberdir. İranlıların Dînkerd'i, Zend'i hatta kullandıkları yazıyı dahi Zerdüşt'e atfetmeleri tesadüf değildir. ${ }^{8}$ Dahası İskender, İran işgali sırasında Diz-i Nibişt'i yaktırdığı ve Ganj-i Şâhîgân'daki bazı metinleri kendi yurduna kaçırdığ 1 için Yunan felsefesi, tıbbı ve astronomisi, aslında İran kaynaklı olmalıdır. Bu nedenle Dînkerd'de, Yunan kaynaklarının bir kısmından isim verilmeden iktibas yapıldığg söylenebilir. Bir iddiaya göre Dînkerd'de kendisinden söz edilen tek filozof, hrōm filāsōfā/ Roma filozofu diye geçen Seneca'dır. Ondan da İranlıların basiretli davranışlarını ve bilgelerini övdügüne dair bir rivayet nakledilmiş, ilgili pasajda

Joseph Peterson, ed., Büyük Bundehişn, çev. Behramgore Tehmuras Anklesaria (Bombay, 1956), b.XXXIII/14.

7 Firdevsî, Şehname I, çev. Necati Lugal ve Kenan Akyüz (Ankara: MEB Yayınları, 1956), 23-24; Ebû Mansûr Abdülmelik b. Muhammed b. İsmâîl es-Sealibî, Ğureru Ahbâri Mülûki'l-Furs ve Siyerihim, çev. Hermann Zotenberg (Paris, 1900), 2.

8 Ebü'l-Hasen Alî b. el-Hüseyn b. Alî el-Mesudî, Kitabu't-Tenbîh ve'l-İşraf (Leiden: Brill, 1893), 90; Dimitri Gutas, Yunanca Düşünce Arapça Kültür, çev. Lütfü Şimşek (İstanbul: Kitap Yayınevi, 2017), 48. 
İran uygarlığının ne kadar önde olduğu anlatılmıştır. Hrōm filāsōfā ifadesinin "Roma filozofları" şeklinde, muayyen bir kişi için kullanılmaksızın yorumlandığı da vakidir. ${ }^{9}$

Sasaniler dönemi, İranlıların "yitik" hikmetlerini bir araya toplama dönemidir. Bu nedenle Sasanilerde, ilim-kültür faaliyetleri canlıdır ve hükümdarlar, din adamlarının yanında filozoflara, tabiplere ve müneccimlere iltifat etmiştirlerdir. Sasani öncesinden tevarüs eden çok sayıda eser Sasani Pehlevicesine çevrilmiş ve bu eserler etrafinda yeni kitaplar yazılmıştır. İnsanlık tarihinin İran uygarlığı üstünden aktarıldığ İ̉an ulusal tarihi de Sasaniler dönemi ve sonrasında ayrı bir ilgiye mazhar olmuştur. Yâdgâr-i Zerîrân, ${ }^{10}$ bu ilginin sonucunda kaleme alınmış ve günümüze ulaşmış en eski metinlerden biridir; ayrıca Orta Farsça/Pehlevice yazılmış, elimizdeki tek kahramanlık anlatısıdır. Bu anlatı, hudayiname/şehname türü eserlere, özellikle Firdevsî’nin Şehnamesinde yer verdiği Dakikî’nin (ö.365370/975-980) Geştaspnâmesine kaynaklık etmiştir. Sasaniler dönemi sonrasında gelişen hamase/destan yazarları, Yâdgâr-i Zerîrân'a yer yer başvurmuş olmalıdırlar. Bu nedenle o, Sasani dönemi sonrasında yazılan destanlar ile dikkat çekici benzerliklere sahiptir. ${ }^{11} \mathrm{Ne}$ var ki Zerdüşt'ün ortaya çıkması, insanları yeni bir dine davet etmesi ve Goştasp Şah'ın bu dine katılması Avesta başta olmak üzere farklı kaynaklarda hikâye edilirken Yâdgâr-i Zerîrân'da yalnızca İran-Turan savaşları bağlamında bir anlatım söz konusudur; Zerdüşt’ten ve davetinden söz edilmemektedir.

Pehleviceden yaptığımız çeviri, metnin İngilizce ve Farsça çevirileriyle notlandırıldığı ve dolayısıyla farklı yorumları aktardığı için Türkiye'deki Sasani tarihi ve kültürü araştırmacılarına büyük kolaylık sağlayacaktır. Pehlevice metindeki müphem ifadeleri kimin nasıl yorumladığı dipnotlarda belirtilmiş, hangi sözcüğü nasıl çevirdiğimiz gerekçeleriyle anlatılmıştır. Bu sayede araştırmacılara farklı bakış açılarını göstermek hedeflenmiştir. Pehlevî dilindeki en eski kahramanlık anlatısının mukayeseli olarak tercümesi, edebiyat tarihi araştırmacılarına da katkı sağlayacak mahiyettedir. Anlatının içeriğini, onu tarihlendirerek ve tanıtarak, burada belirttiğimiz Sasani dönemi egemen tarih anlayışı ve dünya görüşünü de dikkate alarak farklı yönleriyle inceleyelim.

9 Oryan, Dînkerd IV, b.108.

10 Esere Yâdgâr-ı Zerîrân ya da Yâdigâr-ı Zerîrân da denilmektedir.

11 Dakikî, Goştaspname, çev. Nimet Yıldırım (İstanbul: Kabalcı Yayıncılık, 2018), 53 vd. 


\section{Yâdgâr-i Zerîrân'ın Tarihlendirilmesi ve Tercümeleri}

Yâdgâr-i Zerîrân'ın yahut Pehlevice adıla Ayâdgâr-i Zerîrân'in, Partça/ Eşkani Pehlevicesiyle kaleme alınmış bir metnin Sasani Pehlevicesine aktarılmış hâli olduğu kanaati yaygındır. Pehlevice metinde bu fikri destekleyecek Partça sözcükler yer almaktadır ki bu ifadelerin bir kısmı yeterince anlaşılamadığından bunları müphem ifadeler olarak dipnotlarda değerlendireceğiz. Pehleviceye çevirisi yapılan metin ya Sasanilerden önce yazılmış ya da Sasanilerin ilk yıllarında kaleme alınmıştır; zira yazıtlardan anlaşıldığ lanılmıştır. ${ }^{12}$ Metnin orijinalinin şiir olduğu fikri, Christian Bartholomae ve Émile Benveniste'nin başlıca iddiasıdır. Benveniste, metni altılı hece ölçüsü ile düzenlemeye çalışmıştır. ${ }^{13}$ Eğer metnin kaynağı bir şiir ise mevcut metin ya derleme sırasında ya da derlendikten sonra deforme olmuş demektir. Deforme olmuş bir metni tarihlendirmek oldukça zordur. Eğer mevcut metnin bir şiirden değil nesirden aktarıldığı kabul edilirse Partça metnin kaynaklarını sorgulamamız gerekir. Yâdgâr-i Zerîrân'da anlat1lanlar Dinkerd ve Bundehişn gibi klasikler paralelinde okunursa, onun herhangi bir metinden aktarıldığını söylemek zorlaşır; çünkü Dînkerd'in VIII. kitabından anlaşıldığı kadarıyla Avesta neskleri de aynı anlatıyı özetlemiş̧ir. Bu durumda Yâdgâr-i Zerîrân, Sasaniler döneminde başlatılan telif ve derleme faaliyetlerinin bir ürünü addedilebilir ve böylece özgün bir metin olarak Avestaî kaynaklardan hareketle yazıldığı sonucuna ulaşı1ır. Metindeki destansı anlatıların ve savaş gereçlerinden giyim kuşama kadar betimlenen pasajların bir kısmının klasik metinlerde yer aldığı diğer kısmının da birçok Zerdüştî anlatısı gibi şifahi yolla nakledildiği varsay1labilir. Sasanilerin ilk yıllarında Partça kullanılması da metnin karmaşık dilini açıklar. Ancak metnin ilk bendi (Ayâdgâr-i Zerîrân... Viştasp Şah'ın, ... Ohrmazd'dan aldı̆̆ sıra yazıld l) Goştasp Şah dönemine atıf yaptığı için bu senaryo pek tutarlı görünmez ki bu nedenle Partça bir metnin Pehleviceye çevrildiği kanaati yaygındır. Asıl metnin Pehleviceye çevrildiği dönem olarak da miladi V ya da VI. yüzy1l gösterilmektedir. ${ }^{14}$

Perviz Nâtil Hânlerî, Tarih-i Zeban-i Farsî-I (Tahran, 1365), 217.

Yahya Mâhyâr Nevvabî, Yâdgâr-i Zerîrân (Tahran: Esatîr, 1387), 13-14.

Ahmed Tefazzulî, Târîh-i Edebiyyât-i Îrân Pîş Ez İslam (Tahran: Sohen, 1378), 267;

Nimet Yıldırım, Fars Mitolojisi Sözlüğü (İstanbul: Kabalc1 Yayınevi, 2008), 23; Hânlerî, Tarih-i Zeban-i Farsî-I, 224. 
Yâdgâr-i Zerîrân, miladi XIV'üncü asırda İran'dan Hindistan'a yerleşen Zerdüştî mubedi Mihrâbân Keyhüsrev'in, Yezdicerd takvimine göre 691 senesini (miladi 1322) kaydettiği, bugün MK Kodeksi olarak bilinen ve 163 folyodan oluşan koleksiyonda yer almaktadır. Eser ilk defa W. Geiger tarafindan Şahname-yi Goştasp adıyla 1890 senesinde Almanca yayınlanmıştır. Nöldeke, Yâdgâr-i Zerîrân'ı 1892'de yayınlamış ve aynı yıl Geiger'in tercümesini de ele alarak notlandırılmış bir makale hazırlamıştır. 1897 senesinde Jamasp-Asana, bir grup Pehlevi metnini yayımlamış ve Yâdgâr-i Zerîrân'ın baş sayfalarına yer vermiş; tamamını eserin ikinci cildi için hazırlamış, ancak 1898'de vefat edince bu çalışma 1913'te Bombay'da The Pahlavî Texts adıyla basılmıştır. J.J. Modi, 1899'da eseri hem Gocerat diline hem de İngilizceye çevirmiştir. Aynı şekilde metni, 1925'te A. Pagliaro İtalyancaya, 1932'de Benveniste Fransızcaya ve 1935'te Meliku'şŞuara Muhammed Taki Bahâr Farsçaya tercüme etmiştir. Meliku'ş-Şuara, 1935 'teki çevirisini Mecelle-yi Talim ve Terbiyet' in 5. y1lının 3, 4 ve 5. sayılarında parça parça yayınlamış; 1347 (m.1968) tarihli bir kitabında başka bazı metinler ile birlikte ayrıca neşretmiştir. 1943'te Zebîhullah Safâ, Fransızca çeviriyi esas alarak Farsça bir çeviri yapmıştır. Yakın zamanda, 1992 senesinde Said Oryan, Mutûn-i Pehlevî adıyla Jamasp-Asana'nın yayına hazırladığı 32 metni, transkripsiyon alfabesi ve Farsça çevirisi ile birlikte Tahran'da neşretmiştir. Yahya Mâhyâr Nevvâbî, 1374 (m.1995) tarihli bir çeviri yayınlamıştır. 1392 (m.2013) tarihli başka bir çeviri, Jale Âmuzgâr tarafindan yapılmıştır ve bu çeviride fazlaca açıklama bulunmakta, önceki çevirilere sık sık atıf yapılmaktadır. Bu çevirilerin dışında Muhammed Muîn gibi eseri özetleyen ya da bir kısmını çeviren çok sayıda araştırmacı bulunmaktadır. ${ }^{15}$

\section{Yâdgâr-i Zerîrân'ın Konusu ve Kahramanları}

Ayādgār/ayyātkār sözlükte "anı, hatıra" anlamına gelmektedir. ${ }^{16}$ Ayādgār-i Zarēerān, "Zerîr' in Hatırası/Zerîr'in Kitabı" anlamlarına gelir. 114 bent, 346 satırlık bu kısa risalenin konusu; Goştasp/Key Viştasp Şah'ın,

15 Jamaspji Minocheherji Jamasp-Asana (ed.), The Pahlavî Text-II (Bombay: Fort Printing Press, 1913), 14; Mâhyâr Nevvabî, Yâdgâr-i Zerîrân, 11.

16 Henrik Samuel Nyberg, A Manual of Pahlavi (Tahran: Esâtir, 2003), 41; David Neil MacKenzie, A Concise Pahlavi Dictionary (London: Oxford University Press, 1986), 15. 
Zerdüşt'ün davetini kabul etmesi ve bu nedenle Xiyon/Hun hükümdar1 Ercasp'ın, Viştasp Şah'1 tehdit etmesi ile başlayan Keyanî-Hun yahut İranTuran savaşıdır. Bu savaş sırasında Zerîr'in ölümü, trajik biçimde tasvir edilir ve Zerîr'in yedi yaşındaki oğlu Bestûr'un, babasının intikamını alması destansı bir şekilde anlatılır. Savaşı Keyanîler kazanmakta ve Ercasp dışında hiçbir Hun askeri savaştan kurtulamamaktadır. Ercasp ise ibret olması açısından bir eli, bir ayağı ve bir kulağı kesilip bir gözü ateşle yakılarak, kuyruğu kesilmiş bir eşeğin sırtında yurduna gönderilmiştir. Anlatıya Ayādgār-ī Zarēerān ismi sonradan verilmemiştir; metnin ilk bendinde bu isim zikredilmektedir. Olay esnasında Zerîr öldürüldüğü için ve bu numayişname de Zerîr'i yâd ettiği için, eserin bir "taziyename" şeklinde yorumlandığı görülmektedir. ${ }^{17}$

Viştasp Şah'ın, Zerdüşt'ün dinine bağlanması Zerdüştîler açısından büyük önem taşımaktadır. Dünya tarihinin her biri 3 bin yıl tutan 4 dönemden, yani 12 bin seneden ibaret olduğuna dair Zerdüştî telakkisinde, Viştasp Şah'ın yaşadığı dönüşüm son milat kabul edilmektedir. Söz konusu telakkide her bin seneyi bir burç temsil etmekte; Warrag/Koç ile başlayan tarih/ evren, Mahig/Balık ile sona ermektedir. Viştasp Şah'ın Zerdüştîliğe intisabı, bu Zodyak takviminin III. çağını kapatmış ve IV. çağını başlatmıştır; yani Viştasp Şah'ın, Zerdüşt'ün davetine uyduğu dönem, 9 bin senenin dolduğu ve Oğlak burcunun egemenliğinde IV. çağın başladığı dönemdir. ${ }^{18}$ Zerdüşt'ün zuhuru ve Viştasp'ın himayesine girmesi, bir kıyamet alametidir ki bu nedenle hemen bütün Zerdüştî kaynaklarda Viştasp'ın yaşadığı dönüşüm anlatılır ve Avesta' da, Viştasp Yaşt adıyla müstakil bir bölüm altında hikâye edilir.

Yâdgâr-i Zerîrân'da, tanrı ya da insan ismi olduğu belli olmayan "Druvasp" dışında 18 şahıs ismi geçmektedir. Bu isimler şunlardır: Viştasp Şah ve kardeşleri Zerîr ile Pad-Hüsrev, Viştasp Şah'ın karısı ve kız kardeşi Hotes, en sevdiği oğlu Fraşavard ve kızı Humay; Zerîr'in oğlu Bestûr, Keyani Sadrazamı Camasp ve oğlu Goramî; Hun hükümdarı Ercasp ve kızları Zersütûn ile Bisütûn, elçileri Bîderef̧̧ ve Namhast-i Hezarân; ayrıca Başkatip Abarsam/İbrahim, İsfendiyar ve Rüstem. ${ }^{19}$

17 Mâhyâr Nevvabî, Yâdgâr-i Zerîrân, 7.

18 Max Müller, ed., "Bundehişn," içinde The Sacred Books of The East, çev. E.W. West, (Oxford: The Clarendon Press, 1880), b.XXXIV.

19 Eski İran isimlerinin birçoğu, tarım toplumlarında görüldüğü üzere hayvan 
Wištāsp-Ša/Viştasp Şah, hanedanı ile birlikte Zerdüşt'ün davetini kabul eden Keyânî hükümdarıdır. Keyanî hükümdarı olduğu için 39, 63 ve 68 . bentlerde isminin başında "key" unvanı bulunur. "Key" Rig Veda'da "ileri görüşlü, bilge, şair" anlamlarına gelmektedir. Avesta' da, Avesta diline uygun olarak "key" yerine "hükümdar, komutan" anlamında "kavi" sözcügü geçmektedir ki bütün hükümdarlarına "key" unvanı verildiği için bu hanedana Keyanîler denmektedir. ${ }^{20}$ Viştasp Şah'ın metinde yer alan bir diğer sıfatı rām-šahr/râmşehrdir. Bu ifade, "krallığında huzur olan, krallığındaki huzuru koruyan" anlamına gelmektedir. ${ }^{21}$ Ayrıca Sasani hükümdarlarından I. Yezdicerd (399-420) döneminde bastırılan sikkelerde ramşehr lakabı yer almaktadır; yani başka hükümdarlara da bu lakabın verildiği söylenebilir.

Frašāward/Fraşavard, Viştasp Şah'in en sevdiği oğludur ve 59. bentte Viştasp Şah'1 teselli eder. Şah'a teselli verenler arasında kardeşi ve Mezdiyesna inanırlarının ulularından Pād-Husrō/Pad Hüsrev de bulunur. Viştasp Şah'ın kızı Humāg/Humay ile hem karısı hem de kız kardeşi olan Hutōs/ Hotes ise sadece bir yerde ismen zikredilmektedir. Şah'ın Pad Hüsrev d1şında kardeşi olarak ismi geçen diğer kişi, cesur komutan Zarēr/Zerîr'dir. Hun hükümdarı Ercasp, Viştasp Şah'1 tehdit ettiğinde Şah dehşete kapılırken Zerîr, Ercasp'a sert bir mektup gönderen kişidir; bu açıdan anlatının en cesur karakteridir, denebilir. Zerîr'in yedi yaşındaki oğlu Bastwar/Bestûr ise Şah başta olmak üzere kimsenin savaşa katılmama telkinlerini dinlemez ve savaş meydanına giderek babasının intikamını alır.

Keyanîlerin sadrazamı $\hat{J a ̄ m a ̄ s p / C a m a s p ’ t a n, ~ 5 . ~ b e n t t e ~ p e ̄ s ̌ e ̄ n i ̄ g a ̄ n ~ s a ̄ l a ̄ r ~}$ unvanıyla yani "önde gelenlerin lideri, vezirlerin büyüğü" sıfatıyla söz edilmektedir. Bunun dışında Camasp için bìdaxš unvanı kullanılmaktadır. Meliku'ş-Şuara, 35. bent ve sonrasında Camasp için geçen bu sıfatın "müneccim" anlamına geldiğini söylemektedir. ${ }^{22}$ Açıkçası söz konusu pasajda

isimlerinden türetilmiştir. Keyanîler dönemine ait pek çok isim, binek hayvanı olan "at" yahut "deve"den gelmektedir. Yâdgâr-i Zerîrân'da geçen bazı isimler "at" anlamına gelen Sanskritçede āzva, Avesta dilinde aspa ve Pehlevicede asp sözcüğü ile ilişkilidir; Camasp, Viştasp, Druvasp, Ercasp gibi. Bkz: Ulaş Töre Sivrioğlu, Avesta Dili, Grameri ve Etimolojik Sözlüğü (İstanbul: Avesta Yayınları, 2015), 128.

20 Nimet Yıldırım, İran Mitolojisi (İstanbul: Pinhan Yayıncılık, 2015), 135-136.

21 Jâle Âmuzgâr, Yâdgâr-i Zerîrân (Tahran: Muîn, 1392), 29; Nyberg, A Manual of Pahlavi, 166.

22 Meliku'ş-Şuara Muhammed Taki Bahar, "Yâdgâr-i Zerîrân Yâ Şahname-i GoştaspHamase-i Millî-yi İran-i Kadîm," Mecelle-i Ta 'lim ve Terbiyet 5, no. 3 (Hordâd Mâh, 1314): 118. 
Camasp'ın müneccimlik yaptığı görülür; ancak Ercasp, 72. bentte Zerîr'i ve 98. bentte Bestûr'u öldürecek kişiyi Hun ülkesine bïdaxš yapmayı vadetmektedir. Yani sözcüğü "sadrazam" diye tercüme etmek daha doğru olacaktır. Camasp'ın sadrazam ve müneccim olduğu ise metinde açıça belirtilmektedir. Camasp'ın oğlu Garāmīg-kard/Goramî, 106. bentten sonra destana dahil olmaktadır ve kahramanca savaştığı belirtilmektedir.

Hun hükümdarı Arjāsp/Ercasp, Keyanîlerin Zerdüş̧îliğe intisap ettiklerini öğrenince bunun bir felaket nedeni olacağını düşünmüş ve Keyanîleri bu dinden dönmeye çağırmış; aksi halde savaş açmakla tehdit etmiştir. Ercasp'ın Viştasp Şah'a gönderdiği elçiler Wìdrefšs-̄ Ĵādūg/Büyücü Bîderefş ve Nām-xwāst-i Hazārāan/Namhast-i Hezarân'dır ve bu elçilerin, Hun diyarının en yakışıklı kimseleri olduğu ifade edilmektedir. Bîderefş, Zerîr'i öldüren kişidir ve Zerîr'in oğlu Bestûr tarafından öldürülmüştür. Hun hükümdarı Ercasp'ın kızları Zarr-stūn/Zersütûn ve Bēh-stūn/ Bisütûn'un isimleri, yalnızca bir kez Ercasp tarafindan telaffuz edilmiştir.

Rōdastahm/Rüstem ismi 28. bentte Keyanî ordusunun teçhizatı tasvir edilirken benzetme amaçlı yer almaktadır; yani Rüstem, bu destanın kahramanları arasında değildir. 61. bentten sonra ortaya çıkan Spandyād/İsfendiyar gerek Viştasp Şah'1 teselli etmesiyle gerek Ercasp ve ordusuna tek başına saldırmasıyla gerekse Ercasp'ı yakalayıp sakat bırakmasıyla destanın önemli bir karakteridir. Ercasp'ın gönderdiği mektubu okuyan ve Zerîr' in dikte ettiği mektubu kaleme alan kişi Ābrāhēm-ī dibìrān mahist olarak okunmakta; bu nedenle çevirilerde "Başkatip İbrahim" ismi yer almaktadır. Pehlevice metinde 'pl'hym olarak geçen ifadenin Ibrahim olarak okunmas1 mümkün olduğu gibi sözcüğün 'pls'm olarak düzeltilmesi de teklif edilmiştir. Bu sayede sözcük, Semitik dillerdeki İbrahim ismi yerine İran dillerine uygun olarak Abarsām şeklinde okunabilir. ${ }^{23}$

Avesta'da, Zerîr'in ismi "Zairivairi”, Ercasp'ınki ise "kötü Arejat-aspa" şeklinde geçmekte; Viştasp Şah "Kavi Viştaspa" olarak anılmaktadır. Bir üst pasajda Viştasp Şah'ın babasının adı Aurvat-aspa olarak verilmiştir. ${ }^{24}$ Frawardin Yaşt'ta "Kutsal Basta-vairi" olarak sözü edilen kişinin Bestûr olma ihtimali de bulunmaktadır. ${ }^{25}$ Mevcut kaynaklarda Viştasp'ın baba-

\footnotetext{
23 Âmuzgâr, Yâdgâr-i Zerîrân, 15.

24 Yaşt 5/105-117.

25 Yaşt 13/103.
} 
sının adı Lohrasp’tır. Bundehişn, Keyanîlerin soy kütüğünü vermektedir ve bu şecereye göre Keyanî hanedanı, Zerîr'e kadar babadan oğula Key Kobad $>$ Key Apiveh $>$ Key Pisin $>$ Manush $>$ Auzav $>$ Lohrasp $>$ Viştasp ve Zerîr şeklinde sıralanmıştır. ${ }^{26} \mathrm{Bu}$ örnekler, eski kaynaklarda geçen isimlerin zamanla farklı telaffuz edildiğini yahut Sasaniler dönemi derleme faaliyetleri sırasında bazı isimlerin Pehleviceye uygun formlara sokulduğunu göstermektedir. İsimlerdeki dönüşüm ve metnin içinde Partça ve Pehlevice sözcüklerin birlikte kullanılması, eserin yalnızca çoğaltılmadığını, aynı zamanda güncellendiğini gösterir. Ek olarak farklı anlatıların birbirleriyle ilişkili olabileceğine işaret eder ki Zerîr ve Viştasp Şah anlatısı ile Yunanl1lardan nakledilen Zariadres ve Hystaspes bu açıdan ilişkilendirilir. Dilbilimci Friedrich Spiegel, Mytilene'li Chares tarafından yazılmış ve günümüze Athenaeus tarafindan ulaştırılmış "Zariadres ve Odatis" anlatısı ile Viştasp Şah'ın kardeşi Zerîr arasında ilişki kuran ilk kişidir. Sonrasında Mary Boyce, Zerîr ile Zariadres arasındaki ilişki üstüne detaylı bir araştırma yapmış; Avesta dili, Pehlevice, Ermenice ve Partça olarak Zairivairi, Zarēer, Zalēl, Zarwar/Zarūr, Zariadres, Zarehr ve Zareh isimleri üstünde durmuştur. ${ }^{27}$

Zariadres ve Odatis anlatısı, Athenaeus'un aktardığına göre İranlılar arasında şüyu bulmuş bir aşk hikâyesidir. Prenses Odatis ile Prens Zariadres birbirlerini sadece rüyada görerek âşık olmuş; Odatis'in babası Omartes, kızının Zariadres ile evlenmesini onaylamamış ve onu evlendirmek için bir gece tertip etmiştir. Zariadres, İskitli kılığına girerek bu şenliğe gelip Odatis'i yanında götürmüştür. Rüyada başlayan bu aşk hikayesi, Odatis'in kadeh uzatması gibi çeşitli sembollerle detaylandırılmıştır. Athenaeus, oldukça yaygın bir coğrafyada bilinen bu anlatı nedeniyle, Asyalıların/İranlıların Odatis isimini çocuklarına verdiklerini ve bu aşk hikayesinin duvarlara nakşedildiğini aktarmaktadır. ${ }^{28}$

Yâdgâr-i Zerîrân gibi İran-Turan savaşının ele alındığı bir diğer kaynak Geştaspnâme'dir. Dakikî Viştasp'ın Zerdüştîliğe intisabını şiire dökmüş ve Firdevsi, Şehnamesine bu eseri almıştır. Dakikî, büyük bir ihtimalle Yâdgâr-i

Müller, "Bundehişn," b.XXXI/28-29.

27 Mary Boyce, "Zariadres and Zarēr," Bulletin of the School of Oriental and African Studies 17, no. 3 (1955): 466-67.

28 Athenaeus, The Deipnosophists or Banqued of the Learned of Athenaeus III, çev. Charles Duke Yonge (Londra: Henry George Bohn, 1954), 919-20. 
Zerîrân'1 kaynak olarak kullanmıştır. Bununla birlikte bu iki eserin birçok hususta farklılaştığını da söylemek mümkündür. Destanın kahramanları açısından bakarsak Geştaspnâme'ye göre Viştasp, Kayser'in kızı Nâhid ile evlidir ve ona Ketayûn adını vermiştir. ${ }^{29}$ Ketayûn ifadesi Bundehişn'de Feridun'un kardeşlerinin birinin adı olarak yer alır ki Geştaspnâme'nin ilgili pasajında karısını "Ketayûn" adıyla çağıran Viştasp'ın "Feridun olmak istediği”" belirtilmektedir. ${ }^{30}$ Geştaspnâme'ye göre İsfendiyar ve Peşûten, Viştasp ile Ketayûn'un çocuklarıdır. Dakikî’nin kısaca değindiği Viştasp'ın Nâhid ile evliliği konusu, Sealibi'nin eserinde ayrıntılı biçimde anlatılmaktadır. ${ }^{31}$ Araştırma safhasında ayrıca incelediğimiz Geştaspnâme, Nimet Yıldırım tarafından 1109 beyit olarak "Goştaspname" adıyla Türkçeye çevrilmiştir.

Yâdgâr-i Zerîrân, mitsel mekanların hikâyesidir. Ercasp "Hun diyarında", Viştasp ise Iranşehr'dedir. Ercasp'n mektubu nedeniyle Zerîr'in yazdırdığg cevapta, Hunlar savaşa davet edilmektedir. Bu davette savaşmak için belirlenen alan, 19. bentte "çalılık ve murv-i zerdüştânın bulunduğu düzlük" şeklinde tasvir edilmektedir. Murw ì zerduštān/morg-i zerdüştân, Yezdicerd'in katledilmesinden önce öten mitsel bir kuştur. ${ }^{32}$ Metinde, askerlerin konuşlandığ 1 yerler hakkında bilgi verilmez; sadece iki hükümdarın da savaşa birer dağdan komuta ettiği anlatılır. 114. bende göre iki ordu roz frawardīn/farvardin gününde savaşmıştır. Farvardin hem ayın on dokuzuncu günüdür hem de ilk ayın adıdır. Jale Âmuzgâr, 26. bentteki ham spāh diye okunan $<$ HWEm sp'h $>$ ifadesini hamaspahmēdìm şeklinde tamamlayarak 114. bent ile irtibatlandırmıştır. Hamaspathmaidyem, Zerdüştîlerin altı büyük bayramlarından/gâhânbâr biridir ve yılın son beş günü (miladi takvime göre bugün 16-20 Mart arası) kutlanır. Âmuzgâr, metindeki "farvardin gününü” de "farvardinin günü” şeklinde yorumlayarak savaşın Farvardin ayında yani yılın ilk ayında (miladi takvime göre bugün 21 Mart-19 Nisan arası) yaşandığını ifade etmiştir. ${ }^{33}$

\footnotetext{
29 Dakikî, Goştaspname, 183.

30 Müller, "Bundehişn," b.XXXI/8.

31 es-Sealibî, Ğureru Ahbâri Mülûk, 253 vd.

32 Bahâr, "Yâdgâr," 116.

33 Âmuzgâr, Yâdgâr-i Zerîrân, 19, 40.
} 


\section{Yâdgâr-i Zerîrân'daki Dini Kavramlar ve Semboller}

Ateş, hemen her toplumda bir sembol olarak kullanılmıştır; ancak hiçbir toplum İran uygarlı̆g 1 kadar ateşe anlam yüklememiştir. Yâdgâr-i Zerîrân' da ateş, dini bir sembol olarak öne çıkmaktadır. Viştasp Şah, savaş hazırlıklarına başlamadan önce yüksek dağların tepelerinde ateş yaktırılmasını istemiştir. Savaş için kurulacak orduya Behram ateşi ile ilgilenen din adamları dışında herkesin katılmasını istemiştir (23-24. Bent). Behram ateşi/âteş-i vehrâmân, yalnızca yetkili mubedlerin dualar okuyarak yakabildiği en büyük ve en önemli ateştir. Araştırmacıların Zerdüştîlikteki ateş türlerinin sayısı ve işlevleri hakkında farklı görüşler ortaya attıklarını belirterek, Behram ateşinin geceleri dahi yanan, parlak ateşi ile bilinen ve içine atılan ağaçlar nedeniyle güzel bir koku yayan, özel bir ayin ateşi olduğunu söyleyelim. ${ }^{34}$ İlaveten anlatının 70 . bendinde Zerîr, "bir sazlıkta rüzgâr sebebiyle gür biçimde yanan" a dur yazd/Tanrı Azer'e benzetilmiştir. İran kültüründe $A z e r$ ve Hint kültüründe $A g n i$, ilahi güç ve adeta yaşam kaynağıdır. ${ }^{35}$

Metinde asmān/cennet ve dušox/cehennem, mübalağa amaçlı kullanılmıştır; yani herhangi bir cennet-cehennem tasviri yoktur (29 ve 74 . Bent). Anlatıda Bîderefş'in büyülü silahı, cehennemde $d \bar{e} w / d i v l e r$ tarafından yapılmıştır. Divler/daevalar, asuralar ile birlikte eski Hint-İran tanrı grubunun temelini oluşturur. Bu ikili tanrı grubu, madde-mana düalizminin de temeli olmalıdır; çünkü muhtemelen maddi işlerle divler, manevi işlerle asuralar ilgilenmiştir. Hint ve İran kültürü birbirinden bağımsız hâle geldiğinde Persler asuraları, Hintliler ise daevaları ön plana çıkarmıştır. Ahura Mazda'nın en yüce yahut tek ilah kabul edildiği İran dinlerinde divler, cin/ şeytanla ilişkilendirilmiştir. ${ }^{36}$

41. bentte geçen ve yeterince anlaşılmayan Druwāsp/Druvasp, "k1lıcın kabzası" anlamında cins isim, şahıs ismi ya da tanrı ismi olabilir. Zira Bundehişn'de mubedlerin soy kütükleri sayllırken, Viştasp ve Zerîr'in soy kütüğünü andıran bir zincir görülür. $\mathrm{Bu}$ zincir babadan oğula şöyledir: Manush $>$ Durasrobo $>$ Zerîr. Zerîr'in soy kütüğü ise

34 Yıldırım, Fars Mitolojisi Sözlüğü, 100-101.

35 Kürşat Demirci, Hinduizmin Kutsal Metinleri Vedalar (İstanbul: İşaret Yayınları, 1991), 51.

36 Demirci, Hinduizmin Kutsal Metinleri Vedalar, 50. 
Manush $>$ Auzav $>$ Lohrasp $>$ Zerîr şeklindeydi. Lohrasp isminin de deforme olduğunu belirtmiştik. Zerdüşt'ün soy kütüğünde de "Menuş̧̧ihar'ın oğlu Durasrobo" adı geçer ${ }^{37}$ ve Zerdüşt'ün çocukluk dönemi anlatılırken Durasrobo'dan bahsedilir. ${ }^{38}$ Farklı kişilerin soy kütüklerindeki isimlerin şaşırtıcı derecede birbirine benzemesi, Druvasp'ın Lohrasp olduğu kanısını güçlendirmektedir. Nitekim Boyce, bu husustaki şüpheleri artıracak araştırmalar yapmış; Zariadres ile Zerîr arasındaki benzerlikleri gösterirken Druvasp ile Luhrasp sözcüklerine de işaret etmiş ve sözcüğün en başta $A s ̌ i '$ nin bir sıfatı olduğunu, sonradan bağımsız bir ilah formuna dönüştüğünü ileri sürmüş̧ür. ${ }^{39}$ Avesta pasajlarından Drwāspa Yaşt'ta belirtildiği kadarıyla Drvaspa, koruyucu bir tanrı/melektir. O, sürüleri korur; atları koşuma takar, at arabasının tekerini döndürür ve gücüyle inananlara yardım eder. ${ }^{40}$ Ek olarak, metindeki "druvasp" sözcügünün "kılıcın kabzası" anlamına gelme ihtimali de bulunmaktadır. ${ }^{41}$

Yâdgâr-i Zerîrân'da anlatıldığına göre Zerîr'e atılan mızrak/süngü, onun bel kuşağının altından ve kustisinin üstünden sırtına saplanmıştır; yani Zerîr savaş esnasında kustīg/kusti bağlamış bir şekilde tasvir edilmiştir (75. Bent). Kusti, altı iplikle dokunmuş bir kuşaktır ve bu altı ipliğin her biri kuzu ya da oğlak yününden yapılmış on iki iplikten dokunmuştur. Böylece bir kusti yetmiş iki iplikten meydana gelir ve yer yer yün yerine pamuk da kullanılır. Bu yetmiş iki iplik, kuşağın iki ucunda üç adet püskül oluşturmak için eşit biçimde (24X3) ayrılır. Kusti, bel etrafina üç kez sarılır ve biri önde biri arkada, iki kare dügüm yahut resif düğüm ile düğümlenir. Hem kuşağın kendisi hem de üç defa bağlanıp düğümlenmesi, Zerdüştî inançlarının özünü sembolize eder: Hūmat, hūxt ve hūwaršt (iyi düşünce, iyi söz ve iyi iş). Kuşak takmak, üst ile altın, cennet ile cehennemin, bilgelik ile cehaletin ve aydınlık ile karanlığın birbirinden ayrılmasını sembolize eder. Dinin sınırları, kusti ile anlatılır. ${ }^{42}$

\footnotetext{
37 Müller, "Bundehişn," b.XXXII/1.

38 Max Müller, ed., "Dînkerd VII," içinde The Sacred Books of The East, ed. E.W.West (Oxford: The Clarendon Press, 1897), b.3/4-41.

39 Mary Boyce, A History of Zoroastrianism I (Leiden: Brill, 1975), 82; Boyce, "Zariadres and Zarēr," 465.

40 Yaşt 9/1-2.

41 Bahâr, "Yâdgâr," 119.

42 "Kustīg," J. K. Choksy ve F. M. Kotwal, Encyclopædia Iranica, Son erişim: 12 Mart 2019, http://www.iranicaonline.org/articles/kustig
} 
Eserin en çarpıcı bölümlerinden biri, Zerîr öldükten sonra ruhunun Bestûr'a yol göstermesidir. Anlatıyı İranlılar için ayrıcalıklı kılan bölüm de burası olmalıdır; çünkü anlatı, ölmüş kahramanların ruhlarının onlara yardım ettiğini göstermektedir. 104. bentteki ifadeler, Hint-İran düalizmini en açık biçimde yansıttığı gibi metni okuyanları da psikolojik olarak savaşa hazırlamaktadır. Bu nedenle yedi yaşında olan bir çocuğun, babasının ruhu yardımıyla güçlü bir büyücüyü öldürmesi, teolojik ve psikolojik açıdan değerlendirmeye muhtaçtır.

Hotes, Viştasp Şah'ın hem karısı hem de kız kardeşidir. J.J. Modi, 68. bentte geçen "hutōs $\bar{\imath}-m$ xwah ud zan/kız kardeşim ve karım Hotes" ifadesini, "benim için bir kız kardeş gibi olan karım Hotes" diye tercüme etmiştir. Anlaşıldığı kadarıyla Zerdüştî bir din adamı olarak böyle bir ilişkiyi onaylamış görünmek istememiştir. Oysa Ardâvîrâfnâme'de miraca çıkan Nîşabûr, yedi kız kardeşi ile evlidir ve bu evlilikler, onun ne kadar dini bütün bir Zerdüştî olduğunun alameti sayılmaktadır. ${ }^{43}$

Yâdgâr-i Zerîrân, "Pād nām ì Dādār Ohrmazd/Yaratıcı Ohrmazd'ın adıyla" girizgâhı ile başlamaktadır. Yalnızca Yâdgâr-i Zerîrân değil, Bundehişn ve Karname-yi Erdeşir-i Babekan gibi birçok eser; İslam kültüründeki besmele, hamdele ve salvele geleneğine benzer biçimde başlamaktadır. Bu durum, kimi araştırmacılar tarafından tartışma konusu yapılmıştır; ancak bir esere besmeleyi andıracak şekilde başlama geleneğinin kime ait olduğunu belirlemek oldukça zor görünmektedir. ${ }^{44}$

Geştaspnâme ve Şehname'de Zerdüşt'e atıf varken ve özellikle Viştasp'ın Zerdüştîliğe katılması betimlenirken Yâdgâr-i Zerîrân'da Zerdüşt'ten söz edilmemektedir (Dakikî, 2018, s. 184). Bu durum, Ahamenîlerin hangi inancı benimsedikleri tartışmasını hatırlatmaktadır; çünkü Ahamenîlerden kalan yazıtların hiçbirinde Zerdüşt'ün adı yer almamaktadır. Ancak bu yazitlarda Ahura Mazda, Mitra, Anahita gibi tanrı isimlerine ve divlere/ şeytanlara atıf yapılmaktadır ve bu atıflar, kimi araştırmacılar tarafından Ahamenîlerin Zerdüştî sayılması için yeterli görülmüştür. ${ }^{45}$ Yâdgâr-i

43 Ardâvîâfnâme, 87.

44 Ulaş Töre Sivrioğlu, "Pehlevice (Orta Farsça) Bir Tarihî Coğrafya Metni: Šahrestānīhā $\overline{1}$ Ērānšahr," Akademik Tarih ve Düşünce Dergisi 1, no. 3 (Ağustos 2014): 5.

45 Roland Kent, Old Persian (New Haven: American Oriental Society, 1950), 150-57; Jussi Aro, çev. Esko Naskali, "Zerdüşt Muamması," Marmara Türkiyat Araştırmaları Dergisi 1, no. 2 (Sonbahar 2014): 204. 
Zerîrân'da da Zerdüșt'e atıf yapılmaması, bizi iki hususa yönlendirmektedir: Birincisi, Pehleviceye aktarılan metinde bazı kopuklukların olmasıdır. İkincisi ise Sasaniler dönemi öncesinde "Öğretmen Zerdüşt" profilinin henüz oluşmamasıdır ki bu nedenle Eşkaniler döneminde yahut erken Sasani döneminde yazıya döküldüğü varsayılan Viştasp'ın Zerdüştîliğe intisabı hadisesinde Zerdüşt'e atıf yapılmamıştır.

Pehlevice metindeki Partça sözcükler ve muhtemelen derleme faaliyetleri esnasında yapılan hatalar, onun anlaşılmasını güçleştirmektedir. Bundan ötürü metnin içinde yirmiye yakın müphem ifade bulunmakta ve bazı bentleri yeterince anlaşılamamaktadır. Yâdgâr-i Zerîrân'ın tercümelerini mukayese ettiğimizde, müphem ifadelerin her tercümede farklı anlamlandırıldığını görüyoruz. Jamasp-Asana'nın yayınladığı Pehlevice metinden ${ }^{46}$ yaptığımız çeviriyi, J.J. Modi'nin İngilizce tercümesi, Said Oryan'ın Farsça tercümesi ve transkripsiyonu, Meliku'ş-Şuara'nın, Mâhyâr Nevvâbî'nin ve J. Âmuzgâr'ın da Farsça çevirileri ile mukayese ederek müphem ifadeleri göstermeyi uygun bulduk. 114 bentten oluşan ana metne Mihrâbân Keyhüsrev'in 7 bentten oluşan sonsözünü de ekleyerek tercüme ettik. Metinde olmayan, ancak metnin anlaşılması için ilave ettiğimiz sözcükleri köşeli parantez içinde verdiğimizi, şahıs isimlerini ise Geştaspnâme ve Türkçe tercümesine uygun biçimde çevirdiğimizi belirtelim.

\section{Yâdgâr-i Zerîrân'ın Türkçe Tercümesi}

Yaratıcı Ohrmazd'ın adıyla ve iyi talihin alametiyle... Her iyi insana ve iyi işler yapana, özellikle bunu yazana sağlık ve uzun ömür [verile]!

1-Ayâdgâr-i Zerîrân denilen bu [risale], Viştasp Şah'ın, oğulları, kardeşleri, hanedanı ve muhafızları ${ }^{47}$ ile birlikte Mezdiyesna inanırlarının bu temiz

46 Tercüme ettiğimiz Pehlevice metin, Jamasp-Asana'nın yayına hazırladığı, 1913 yılında Bombay'da yayınlanmış olan eserde yer almaktadır. Bkz. Jamasp-Asana (ed.), Corpus of Pahlavi Texts, (Bombay, 1913), s.1-17. Tercüme ettiğimiz metnin ilk sayfası için bkz: EK-1.

47 Partça kökenli olan ham harzān $\bar{\imath} x w e \bar{s}$ ifadesi, Âmuzgâr tarafindan hemalân-i hîş/kendi denkleri, akranları ya da eşleri diye çevrilmiş; Meliku'ş-Şuara, ifadeye hemgonân-i hîş/kendi adamları, akranları; yakınındaki topluluk anlamı vermiş ve sözcüğün "şan sahibi, kıymetli kişi" anlamına gelebileceğini belirtmiştir. Bkz: Bahâr, "Yâdgâr," 115; Âmuzgâr, Yâdgâr-i Zerîrân, 14. Modi'nin çevirisinde equalleş sözcüğü kullanılmıştır. Bkz: Jivanji Jamshedji Modi, Aiyâdgâr-i-Zarirân (Bombay: Education Society's Steam Press, 1899), 3. Bu çevirileri ve Nyberg ile MacKenzie'nin lügatlerini de dikkate 
dinini Ohrmazd'dan aldığı sıra yazıldı. 2-Arkasından, Hun hükümdarı Ercasp, Viştasp Şah'ın, oğulları, kardeşleri, hanedanı ve muhafizları ile birlikte, Mezdiyesna inanırlarının bu temiz dinini Ohrmazd'dan kabul ettiği haberini ald1. 3-Bu [haberden] sonra çok sinirlendi. ${ }^{48}$ 4-Büyücü Bîderefş ve Namhast-i Hezarân'1, iki tümen ${ }^{49}$ seçkin askerle beraber, mesaj iletmeleri için, İranşehr'e gönderdi. 5-Bunun üzerine önde gelenlerin lideri ${ }^{50}$ Camasp, hemen Viştasp Şah'ın huzuruna çıktı ve ona [şöyle] dedi: “Hun hükümdarı Ercasp’tan iki elçi geldi ki Hun diyarının tümünde onlardan daha yakışılkl ${ }^{51}$ [kimse] yoktur. 6-Biri Büyücü Bîderefş ve diğeri Namhast-i Hezarân. Yanlarında da iki tümen seçkin asker var. Elinde bir mektup tutuyor ve <Bizi Viştasp Şah'ın huzuruna çıkarın!> diyorlar." 7-Viştasp Şah "Bırakın, huzuruma gelsinler!" dedi.

8-Sonra [iki elçi, Şah'ın] huzuruna çıtılar. Viştasp Şah'a saygılarını gösterdiler ve mektubu verdiler. 9-Başkatip Abarsâm² ${ }^{52}$ ayağa kalktı ve mektubu yüksek [sesle] okudu. 10-Ve mektupta şöyle yazılmışt1: "Ben duydum ki zatıaliniz, ${ }^{53}$ Mezdiyesna inanırlarının bu temiz dinini, Ohrmazd'dan kabul etmiş. Ĕger bu [din]den dönmezseniz, bu bize ă̆ır bir ziyana ve büyük slkıntılara neden olur. 11-Eğer zatıaliniz, bu saf dinden vazgeçmeyi uygun görür [ve] bizimle aynı dine inanırsa, bu durumda sizi hükümdar olarak

alarak "hükümdarın muhafızları" anlamı vermek daha uygundur. Bkz: MacKenzie, $A$ Concise Pahlavi Dictionary, 41; Nyberg, A Manuel of Pahlavi, 92.

48 "Çok sinirlendi" diye çevirdiğimiz garān dušxwārīh ifadesi, "çok sıkıntılı, çok zor, çetin bir hâl, müşkül, tatsızlık" gibi anlamlara gelmektedir. Metnin başka yerlerinde de bu ifade geçmektedir. Bu ifadenin geçtiği her yerde bağlama göre Türkçeye en uygun anlamı vermeye çalıştık.

49 "Tümen" diye çevirdiğimiz bēwar sözcüğ̈̈ "on bin" demektir. Bkz: Bahâr, "Yâdgâr," 115; Âmuzgâr, Yâdgâr-i Zerîrân, 14. Sözcüğe aynı zamanda "sayısız, pek çok" anlamı da verilmiştir. Bkz: MacKenzie, A Concise Pahlavi Dictionary, 18; Modi, Aiyâdgâr-iZarirân, 3. Kahramanlık anlatılarındaki mübalağa göz önüne alınırsa "tümen" sözcüğü Türkçeye en uygun çeviridir.

50 Pehlevice metinde geçen pēşēnīgān sālār ifadesi (pîşîniyân sâlâr) "önde gelenlerin, soyluların, asillerin başındaki kişi" anlamına gelir; yani "sadrazam" demektir.

$51 \quad H u$-čihr sözcüğü "yüz güzelliği” anlamına gelir. Nitekim bu metinde aynı ifade Viştasp'ın ve Ercasp'ın kızları için de geçmektedir. Âmuzgâr, burada “iyi huylu, güzel tabiatlı" anlamını tercih etmektedir. Bkz: Âmuzgâr, Yâdgâr-i Zerîrân, 15.

52 Mâhyâr Nevvâbî, İbrahim ve Abarsam isimlerini değerlendirmekte; Aramî kökenli bir başkatibin sarayda bulunma ihtimaline dikkat çekmektedir. Bkz: Mâhyâr Nevvâbî, Yâdgâr-i Zerîrân, 83.

53 “Zatıaliniz” diye çevirdiğimiz ifade bayān/bağan sözcüğü, “efendi, bey” gibi anlamlara gelen yüceltme anlamlı bir sözdür. 
tazim ederiz. Size yıldan yıla bolca altın, bolca gümüş, fazla sayıda iyi at [öderiz] ve çok yerin hükümranlığını veririz. 12-Fakat eğer bu dinden dönmez ve bizimle ayn dine inanmazsanız size [saldırmaya] geliriz. Tahıllart yer, kurulart yakarız. Ülkedeki dört ayaklıları ve iki ayaklıları esir alır; size acımasız bir kölelik ve sıkıntı veren işler [yapmayı] emrederiz."

13-Viştasp Şah, bu sözleri duyunca derinden sarsıld1. 14-Ordunun cesur komutanı, cengâver Zerîr, Viştasp Şah'1 endişeli görünce hemen huzuruna geldi. 15-Ve Viştasp Şah'a dedi ki “Eğer zatıaliniz müsaade buyurursa ben bu mektuba bir cevap yazdıracağım. ${ }^{54 "}$ 16-Viştasp Şah, "Mektuba bir cevap yaz!" diye emretti.

17-Cesur komutan, kahraman Zerîr, bu mektuba [şöyle bir] cevap yazdırd1:55 "Iran hükümdarı Viştasp Şah'tan Hunların hükümdarı Ercâsp'a selam [olsun]. 18-Evvela biz, bu temiz dinden dönmeyiz ve sizinle ayn dine inanmaylz. Biz bu dini Ohrmazd'dan aldik ve birakmaylz. Ve gelecek ay, sizinle ölümsüzlüğü tadacağız. ${ }^{56}$ 19-Orada, boş bir çalllık ${ }^{57}$ ve murv$i^{58}$ zerdüştân [var] ki ne yüksek bir dăg ne derin bir göl [bulunur]. O düz ovada atlarımı [ve] kahraman piyadelerimiz savaş [sonucunu] belirlesin! 20-Siz oradan gelin, biz de buradan gelelim ve siz bizi görün, biz de sizi görelim! 21-Yezdan'ın eliyle, şeytanın nasıl yok edildiğini size gösterelim!’ 22-Başkatip Abarsâm, mektubu mühürledi ve Büyücü Bîderefş [ile]

${ }^{54}$ Aslında "Mektuba bir cevap yazılmasını emredeceğim!"

55 Aslında "Mektuba cevap yazılmasinı emretti."

56 Anōš xwarēm, metindeki müphem ifadelerden biridir. Modi, bu müphem ifadeyi "gelecek ay siz olmadan ölümsüzlügü tadacağız” şeklinde çevirmiş ve "İyi Zerdüştîler olacağız!" diye yorumlamıştır. Meliku'ş-Şuara, "Size ölümü tattıracağız" diye tercüme etmiştir. MacKenzie, bu müphem ifadeyi "ölümüne savaşmak" olarak anlamlandırmıştır. Bkz: Modi, Aiyâdgâr-i-Zarirân, 12; Bahâr, "Yâdgâr," 116; MacKenzie, A Concise Pahlavi Dictionary, 15.

57 Hutōs ̄ razūr, Said Oryan tarafindan "Hotes ormanı" diye çevrilmiş; Modi de bir yer ismi olarak görmüştür. Bkz: Modi, Aiyâdgâr-i-Zarirân, 9; Said Oryan, Mutûn-i Pehlevî (Tahran: Kitâbhâne-i Millî, 1371), 50. Yer ismi olarak Hoten'e işaret edilmiştir; ancak Mâhyâr Nevvâbî, savaşmak için ormandan ziyade boş bir alanın bu pasaja daha uygun olduğu gerekçesiyle "bîşe-yi tohî/boş çalılık" anlamını tercih etmiştir. Âmuzgâr, bu kanıyı paylaşmakta ve Meliku'ş-Şuara da buna yakın bir anlam yüklemektedir. Bkz: Mâhyâr Nevvâbî, Yâdgâr-i Zerîrân, 84-85; Âmuzgâr, Yâdgâr-i Zerîrân, 18; Bahâr, "Yâdgâr," 116.

58 Murv-i zerdüştân ifadesini açılamıştık. Farklı bir yorum olarak Âmuzgâr, "çim, çimenlik, çayır" anlamındaki "çemen" sözcüğünü teklif etmektedir. Bkz: Âmuzgâr, Yâdgâr-i Zerîrân, 18. 
Namhast-i Hezarân mektubu aldılar; Viştasp Şah'a saygılarını gösterdiler ve gittiler.

23-Sonra Viştasp Şah, kardeşi Zerîr'e emretti: “Dağ başlarında [ve bir de] yüksek dağda ateş yakılmasını emret! 24-Ülkeyi haberdar et! Elçilere haber ver ki suya ve Behram ateşine övgüde bulunup onu koruyan din adamları dışında, on yaşından seksen yaşına kadar hiç kimse evinde kalmasın! 25-[Herkes] diğer ay ${ }^{59}$ Viştasp Şah'ın sarayına gelecek [biçimde] hareket etsin! Eğer o zaman gelmezler, silahların beraber getirmezlerse, orada, [yaşadıkları yerlerde] asılmalarını emrederiz! ${ }^{600}$ ",

26-Sonra herkese, elçiyle haber ulaşt1; Hamaspehmedîm 'de ${ }^{61}$ Viştasp Şah'ın sarayına geldiler. Davul çaldılar, boru üflediler, boynuzlardan ses çıkardılar. 27-Kafile halinde hareket ettiler. Fil sahibi olan fil ile gitti. Binek hayvanı olan [sadece] hayvanıyla, [hayvanların çektiği] arabası olan arabasıyla gitti. 28-[Yanlarında] Rüstem'inkine benzer çok sayıda kılıç ${ }^{62}$, oklarla dolu fazla sayıda kubur, bir hayli madenî zırh ${ }^{63}$ ve dört [katl1] zırh vard1. 29-İranşehr ordusu ${ }^{64}$ öyleydi ki sesi cennete ulaşmıştı; yankısı ise cehenneme varmıştı. 30-Yürüdükleri yola, su bulmak için bir kanal/geçit açtılar. Bir ay boyunca su bulamadılar. ${ }^{65}$ 31-Elli gün boyunca aydınlık bir

59 Ayrıca 114. bendin açıklamasına bakınız.

60 J.J. Modi, burada farklı bir senaryodan bahsetmektedir. Ona göre bu cümle şöyle çevrilmelidir: "Eğer iki ay içinde gelmeyeceklerse darağaçlarını da yanlarında getirmesinler! Biz, onların, kendi yurtlarında darağacına asılmalarını emrederiz." Bkz: Modi, Aiyâdgâr-i-Zarirân, 11. Farklı çevirinin nedeni dār sözcügüdür. Bu sözcük "ağaç, darağacı" anlamına geldiği gibi silahlarla ilgili bir gereç için de kullanılmıştır. $\mathrm{Bu}$ nedenle "Eğer dâr ile beraber gelmezseniz kendi yurdunuzda dâra asılmanızı emrederiz" biçiminde bir edebi sanat söz konusudur. Bkz: Âmuzgâr, Yâdgâr-i Zerîrân, 19; MacKenzie, A Concise Pahlavi Dictionary, 24.

61 Diğer araştırmacılar, buraya "hemsipahî" anlamı verirken Âmuzgâr'ın bu yorumu oldukça makul görünmektedir. Yılın son beş günü kutlanan bayramlardan biri olan Hamaspathmaidyem, bu pasaja anlam olarak daha uygundur.

62 Metindeki šifarg ya da šafrag sözcüğü, Said Oryan tarafından "ok”, Modi tarafindan "mızrak", Meliku'ş-Şuara tarafından "kalkan", Mâhyâr Nevvâbî ve Âmuzgâr tarafindan "k1lıç" olarak tercüme edilmiştir. Bkz: Bahâr, "Yâdgâr," 118; Âmuzgâr, Yâdgâr-i Zerîrân, 20; Oryan, Mutûn-i Pehlevî, 51; Modi, Aiyâdgâr-i-Zarirân, 11; Mâhyâr Nevvâbî, Yâdgâr-i Zerîrân, 87.

63 Yahut “örgülü zırh.” Bkz: Mâhyâr Nevvâbî, Yâdgâr-i Zerîrân, 87.

64 Metinde kārawan/kafile.

${ }^{65} \mathrm{Bu}$ bendi farklı biçimde yorumlayanlar olmuştur. Modi, İranlıların yolu kazmaları sonucu ortaya çıkan toz-toprak nedeniyle nehrin tıkandığını ve havanın kirlendiğini; su içmenin mümkün olmadığını söylemektedir. Bkz: Modi, Aiyâdgâr-i-Zarirân, 13. 
gün görmediler. Kuşlar, atların başları ve mızrak uçları veya oturdukları tepesi yüksek dağlar dışında konacak bir yer bulamadılar. Toz ve dumandan, gece ile gündüz ayırt edilemiyordu. 32-Bunun üstüne Viştasp Şah, kardeşi Zerîr'e [şöyle diyerek] emir verdi: "Iranlıların kamp yapacağ bir kamp kurun! Bu şekilde biz de gece mi gündüz mü, bilelim!"

33-Sonra Zerîr, araba ${ }^{66}$ [yolunun] dışına çıktı ve çadır kurdu. İranlılar da [orada] çadır kurdu. Toz duman gitmeye başladı. Yıldızlar ve ay, gökyüzünde belirdi. 34-Sonra üç yüz demir kazık çakıldı ve onlara üç yüz ip bağlandı ki her ipe üç yüz altın zil asılıydı. 35-Ardından Viştasp Şah, Keyanî tahtına oturdu ve Sadrazam Camasp'ı yanına çağırdı. Ona [şöyle] dedi: "Biliyorum ki sen, Camasp, bilgesin; gören ve taniyan" birisin. 36On günde ne kadar yağmur yă̆ar, yere kaç damla düsser, kaç damla kaç damlanın üstüne düşer; bunları biliyorsun! 37-Çiçeklenen bitkiyi [biliyorsun]; hangi bitki [bu] gün çiçeklendi, hangi bitki gece çiçeklendi ve hangi bitki yarın çiçeklenecek, bunları biliyorsun! 38-Hangi bulutun ${ }^{68}$ yağmur taşıdı̆̆ını ve hangisinin yağmur taşımadığını da biliyorsun! 39-Ejderha takımyıldızına [göre] yarın, Viştasp'ın savaşında ne olacak, bunu da biliyorsun! [Öyleyse söyle bana] benim, Key Viştasp Şah'ın, oğullarım ve kardeşlerimden, kim yaşayacak ve kim ölecek?"

40-Sadrazam Camasp dedi ki "Keşke annemden doğmamış olsaydım! Ya da doğduysam kendi talihimle çocukken ölseydim! Ya da kuş olsaydım [ve bir] denize düsseydim! Yahut zatıaliniz bana bu soruyu sormamış olsaydı! Fakat siz bunu sorduğunuz için [konuşmak] istemez oldum, ĕger gerçeği söyleyeceksem! 41-Ĕ̆er zatıaliniz uygun görürse sağ elini öne çıkarsın ${ }^{69}$ ve Ohrmazd'in ihtişamı, Mezdiyesna inanırlarının dini ve kardeşi Zerîr'in canı üstüne yemin etsin! Çelik ve parlak kılıcını, çene kemiğinden yapılmış okunu Druvasp için üç kez ovsun ${ }^{70}$ ve $<$ Sana vurmayacağım, seni öldürme-

${ }^{66}$ Modi’ye göre “yürüyüş yolu.” Bkz: Modi, Aiyâdgâr-i-Zarirân, 13.

67 Meliku'ş-Şuara'ya göre "yıldızları tanıyan"; Âmuzgâr'a göre "her meseleyi bilen ve tanıyan.” Bkz: Bahâr, "Yâdgâr," 119; Âmuzgâr, Yâdgâr-i Zerîrân, 22.

68 Midarg ya da mētarag Yunanca kökenli bir kelimedir ve "bulut" demektir. Modi, bu sözcüğü breeze/rüzgâr diye çevirmiştir. Bkz: Modi, Aiyâdgâr-i-Zarirân, 15; Mâhyâr Nevvâbî, Yâdgâr-i Zerîrân, 89.

$69 \mathrm{Bu}$ ifade anlaşılmamaktadır ve anlaşılmadığ "Elini kalbine koysun" tercümesi de uygundur. Bkz: Bahâr, "Yâdgâr," 119.

$70 \mathrm{Bu}$ ifadeler de yeterince anlaşılmamaktadır ve tercümeler, buradaki seremoniyi birbirinden farklı yorumlamaktadır. Bu pasajı anlayabilmek için Zerdüştîlikte söz 
yeceğim; Viştasp'ın savaşında ne olacă̆ını söylediğinde öfke duymayacağım!> [diye söz versin ki gerçeği anlatayım.]"

42-Sonra Viştasp Şah [şöyle] dedi: “Ohrmazd'ın ihtişamı, Mezdiyesna inanırlarının dini ve kardeşim Zerîr' in canı üstüne yemin ederim ki sana vurmayacağım, seni öldürmeyeceğim, sana öfkelenmeyeceğim!" 43-Bunun üstüne Sadrazam Camasp konuştu: "Eğger zatıaliniz uygun görürse Iranşehr'in büyük ordusuna, şahın çadırına bir ok atımı mesafesinden uzakta oturmasını emretsin!" 44-Viştasp Şah, İranşehr'in büyük ordusuna Viştasp Şah'ın çadırına bir ok atımı mesafesinden uzakta oturmasını emretti. 45-Sadrazam Camasp [şöyle] dedi: "[Benden] daha şanlı olan kişi ya annesinden doğmamıştır ya doğar doğmaz ölmüştür ya da çocukluğundan gençliğine varamamıştır. 46-Yarın yiğit yiğitle, cesur cesurla savaşacak! Nice anneler çocuksuz, nice oğullar babasız, nice babalar evlatsız, nice kardeşler kardeşsiz ve nice kadınlar kocasız kalacak! 47-Heyecan ve görkemle giden nice Iran atlısı, Hunların hükümdarını arayacak ve bulamayacak! 48-Şanslı kişi, [o gün] Büyücü Bîderefş’i görmeyen kişidir ki [o gün Bîderefş] gelecek, savaşı kızıştıracak, günaha girecek; kardeşinizi, kahraman komutan Zerîr'i öldürecek! Zerîr'in atını, demir toynakl siyah atını, alıp götürecek! [Şanslı kişi, o gün Namhast-i Hezarân'ı görmeyen kişidir ki] Nâmhâst-i Hezarân gelecek, savaşı kızıştıracak, günaha girecek; kardeşinizi, Mezdiyesna inanırlarından ulu Pâd-Hüsrev'i öldürecek, onun altın zırhlı atını alıp götürecek! [O gün] Nâmhâst-i Hezarân gelecek, savaşı kızıştıracak, günaha girecek; doğduğunda bir mızrağın yarı boyunda olan ${ }^{71}$ ve size diğer çocuklarınızdan daha yakın/dost olan, oğlunuz Fraşavard'ı öldürecek! 49-Oğullarınız ve kardeşlerinizden yirmi üç kişi öldürülecek!"

50-Bu sözleri işiten Viştasp Şah, kutlu tahtından yere düştü. 51-Sol eline bir bıçak, sağ eline bir kılıç aldı, Camasp'ın üstüne hücum etti ve [şöyle] dedi: "Dürüst ol sahtekârr" büyücü! [Yalancisın] çünkü annen büyü-

verme ve yemin etme uygulamalarını incelemek yol gösterici olacaktır. Ayrıca buradaki druvasp sözcüğü, kılıcın kabzası için de kullanılmış olabilir. Bkz: Bahâr, "Yâdgâr," 119. Böyle düşünülürse "Kılıcın kabzasına kadar üç defa ovsun!" anlamına gelir.

71 Doğduğunda bir mızrağın yarı boyunda olması, Âmuzgâr'ın yorumudur; zira buradaki ifadeler yeterince anlaşılamamaktadır. Modi “doğduğundan beri Kaiba kalesi civarında yaşayan" anlamını vermektedir. Bkz: Âmuzgâr, Yâdgâr-i Zerîrân, 26; Modi, Aiyâdgâri-Zarirân, 23.

72 Sahm-spār sözcüğü tam olarak anlaşılamamaktadır. Bu nedenle sehmgîn/korkunç 
cü, baban da yalancrydı! 52-Yoksa bu sözleri söylemezdin! Ohrmazd'in ihtişamı, Mezdiyesna inantrlarının dini ve kardeşim Zerîr'in canı üstüne yemin etmeseydim, bıçağın ve kılıcın yalımıyla başını keser, yere atardım." 53-Camasp [şöyle] dedi: "Ĕger zatıaliniz uygun görürse topraktan kalksın ve tekrar Keyânî tahtına otursun! Ne olmaliysa, o olacaktır! Zira benim söylediklerim gerçekleşecektir!" 54-Viştasp Şah, ayağa kalkmadı ve yerine geçmedi. ${ }^{73}$ 55-Sonra cesur komutan, kahraman Zerîr geldi ve [şöyle] dedi: "Eğer zatıaliniz uygun görürse topraktan kalksın ve tekrar Keyânî tahtına otursun! Çünkü ben yarın on beş tümen Hun askerini kendi gücümle öldüreceğim!" 56-Viştasp Şah, ayağa kalkmadı ve yerine geçmedi. 57-Ardından Mezdiyesna inanırlarından ulu Pâd-Hüsrev geldi ve [şöyle] dedi: "Eğer zatıaliniz uygun görürse topraktan kalksın ve tekrar Keyânî tahtına otursun! Çünkü ben yarın gideceğim ve on dört [tümen] Hun askerini kendi gücümle öldüreceğim!" 58-Viştasp Şah, ayağa kalkmadı ve yerine geçmedi. 59-Sonra Viştasp Şah'ın oğlu Fraşavard geldi ve [şöyle] dedi: "Ĕger zatıaliniz uygun görürse topraktan kalksın ve tekrar Keyânî tahtına otursun! Çünkü ben yarın gideceğim ve on üç tümen Hun askerini kendi gücümle öldüreceğim!' 60-Viştasp Şah, ayağa kalkmadı ve yerine geçmedi. 61-Sonra güçlü, kahraman İsfendiyar geldi ve [şöyle] dedi: "Ĕger zatıaliniz uygun görürse topraktan kalksın ve tekrar Keyânî tahtına otursun! Çünkü ben yarın gideceğim ve Ohrmazd'ın ihtişamı, Mezdiyesna inanırlarının dini ve zatıalinizin canı üstüne yemin ederim ki o savaşta Hunlardan hiçbirini să̆ bırakmayacă̆ım!"

62-Bunun üstüne Viştasp Şah ayağa kalktı ve Keyanî tahtına oturdu. Sadrazam Camasp'ı huzuruna çağırdı ve [ona şöyle] dedi: "Senin, Camasp'ın, bu söylediklerin gerçekleşmesin diye madeni bir kale [yapılmasını] emrederim; bu kaleye, demir kapı [yapılmasını] emrederim. Onların, [yani] oğullarımın, kardeşlerimin ve hanedanın bu kaleye girmesini ve oturmasını emrederim. Belki [bu sayede] düşmanın eli onlara ulaşmaz." 63-Sadrazam Camasp [şöyle] dedi: "Eğer madeni bir kale [yapılmasını] emrederseniz; sizin, Ramşehr Key Viştasp Şah'ın, oğullarının, kardeşlerinin ve hanedanın bu kalede kalmasinı emrederseniz, bu kadar düşmana ülkenizde

anlamı verilmiştir. Bkz: Bahâr, "Yâdgâr," 120. Modi, deceitful/düzenbaz sözcüğünü tercih etmektedir. Bkz: Modi, Aiyâdgâr-i-Zarirân, 25.

73 "Yerine geçmedi" diye çevirdiğimiz ifade "vazgeçmek, geri dönmek, pişman olmak" anlamındaki "bâz geşten" fiilidir. Fiil, metinde abāz nigerēd diye kullanılmıştır. 
nasil engel olacaksinız? 64-Kardeşiniz, cesur komutan, kahraman Zerîr, nasıl gidecek ve on beş tümen Hun askerini öldürecek? Mezdiyesna inanırlarından ulu Pâd-Hüsrev nasıl gidecek ve on dört tümen Hun askerini öldürecek? Oğlunuz Fraşavard, nasll gidecek ve on üç tümen Hun askerini öldürecek?" 65-Viştasp Şah [şöyle] dedi: "Şimdi kaç Hun ordugâhtan" gelecek? İlk önce kaç [asker] gelecek, kaçı ölecek ve kaçı geri dönecek?” 66-Sadrazam Camasp [şöyle] dedi: "Yüz otuz bir tümen Hun ordugâhtan gelecek ki bir defa geldiklerinde Hunların hükümdarı Ercasp dışında kimse să̆ kalmayacak! 67-Kahraman İsfendiyar onu yakalayacak! Onun [bir] elini, [bir] ayağını ve [bir] kulağını kesecek; [bir] gözünü ateşle yakacak! Sonra onu kuyruğu kesilmiş bir eşeğe bindirip ülkesine gönderecek ve [şöyle] diyecek: <Git ve [ülkendekilere], benim elimden, Kahraman Isfendiyar'in [elinden] ne gördüysen söyle!>” 68-Viştasp Şah [şöyle] dedi: "Eğer benim, Key Viştasp Şah'ın, her oğlu, her kardeşi ve hanedanı [öldürülse]; ayrıca karım ve kız kardeşim olan Hutos, doğurduğu klz ve erkek otuz evladımla beraber öldürülse, ben Ohrmazd'dan almış olduğum bu temiz Mezdiyesna dininden dönmem!" 69-Sonra Viştasp Şah, bir dağın tepesine oturdu/yerleşti. Beraberinde on iki defa on iki tümen gücü vardı. Hunların hükümdarı Ercasp, bir dağın tepesine oturdu/yerleşti. Onun ise on iki defa on bin tümen gücü vard1. ${ }^{75}$

70-Cesur komutan, kahraman Zerîr; savaş meydanında öyle cengâverdi ki bir sazlığa düşmüş ve rüzgârdan yardım almış Tanrı Azer gibiydi. Kılıcını ileriye savurduğunda on, geriye salladığında on Hunu öldürdü. Acıktığında

74 Metinde bunag sözcügü geçmektedir ve bu sözcük "kamp, kamp yeri” anlamlarına gelmektedir. Bkz: Nyberg, A Manuel of Pahlavi, 50.

75 Anlatıya göre Viştasp Şah'ın yanındaki asker sayısı 1.440 .000 ve Ercasp'ın yanındaki asker say1s1 ise 1.200 .000 .000 'dur. Metinde, $12 \mathrm{X} 12 \mathrm{X} 10.000$ ve $12 \mathrm{X} 10.000 \mathrm{X} 10.000$ şeklinde iki sayı verilmektedir. Bu sayılardan "10.000" farklı yerlerde mübalağa amacıyla kullanılmış ve tarafımızca "tümen" olarak tercüme edilmiştir. Metnin 6. bendi buna örnektir. "12" sayısı ise sadece burada karşımıza çıkmıştır. Bu iki hesabın, Türk kültüründeki "kırk bin kere" sözüne benzer biçimde abartı amacı taşıdığını düşünüyoruz. Ayrıca Jamasp-Asana'nın yayına hazırladığı Pehlevî metinlerine giriş yazısı yazan Behramgore Tahmuras Anklesaria, Yâdgâr-i Zerîrân'1 tanıtırken Ercasp'ın asker sayısını 120.000.000 olarak vermektedir. Bkz: Jamasp-Asana (ed.), The Pahlavî Text-II, s.15. Camasp'ın kehanetinden hemen sonra hükümdarların dağlara konuşlanması ve Zerîr'in kahramanlığının anlatılması, burada bir kopukluk olduğu hissini uyandırmaktadır Nitekim Geştaspnâme'de savaşın başlaması ayrıca hikâye edilmektedir. Bkz: Dakikî, Goştaspname, 213 vd. Bu tür kahramanlık anlatılarında, savaşın başlama anı, ciddi bir önem taşır. Ancak Yâdgâr-i Zerîrân'da böyle bir bölüm bulunmamaktadır. 
ve susadığında Hun kanını gördü ve mutlu oldu. 71-Hunların hükümdarı Ercasp, [bulunduğu] dağın tepesinden [olanları] gördü ve [şöyle] dedi: "Siz Hunlardan kim gidecek, Zerîr ile çarpışacak ve o cesur komutan, kahraman Zerîr'i öldürecek? Bunu yapacak birine, kızım Zersütûn'u eş olarak veririm ki bütün Hun yurdunda [benim klzımdan] daha güzel bir kadın yoktur. 72-[Zerîr'i öldürecek kişiyi] bütün Hun yurduna sadrazam yapacağım. Çünkü eğer Zerîr geceye kadar hayatta kalırsa, uzak olmayan bir zamanda, biz Hunlardan hiç kimse sağ kalmaz!" 73-Sonra Büyücü Bîderefş ayağa kalktı ve [şöyle] dedi: "Gitmem için bir atı eyerleyin!"

74-Bir ata eyer vuruldu ve Büyücü Bîderefş ona bindi. Şeytanların, cehennemde gazap ve zehirle yaptıkları ve günah suyuyla yıkadıkları büyülü mızrağ ${ }^{76}$ ald1. [Mızrağ1] elinde tuttu ve savaşa hücum etti. Zerîr'in nası1 kahramanca savaştığını gördü. Doğrudan [Zerîr'in] karşısına çıkamazdı. 75-Arkasından gizlice yanaştı; saldırdı ve [mızrağı] Zerîr'in, bel kuşağının altından ve kustisinin üstünden sırtına sapladı ve kalbine geçirdi. [Zerîr'i] yere attı; yayların ok atma sesleri ve yiğit adamların haykırışları dindi! 76-Sonra Viştasp Şah, [bulunduğu] dağın tepesinden [olanları] gördü ve [şöyle] dedi: "Sanıyorum ki biri, Iran komutanı Zerîr'i öldürdü; çünkü artık yaylardan gelmiyor ve yiğit adamların haykırışları duyulmuyor! 77-Siz Iranlılardan kim gidecek ve Zerîr'in intikamını alacak? [Zerîr' in intikamını alan] kişiye, kızım Humay'ı eş olarak veririm ki bütün Iran yurdunda, ondan daha güzel bir kadın yoktur. 78-Ona [ayrica], Zerîr'in evini ve Iran komutanlı̆̆ını veririm."

79- Zerîr'in yaklaşık yedi yaşında olan oğlu hariç, asillerden ve yiğitlerden kimse cevap vermedi. [Zerîr'in oğlu] ayağa kalktı ve [şöyle] dedi: "Bana bir at eyerleyin ki gideyim ve yiğitlerin savaşını göreyim; Viştasp hanedanini ${ }^{77}$ göreyim ve babam, o cesur komutan kahraman Zerîr, hayatta mı yoksa ölmüs mü [göreyim]. Zatıalinizi durumdan haberdar edeyim." 80-Viştasp Şah [şöyle] dedi: "Sen gitmeyeceksin! Çünkü henüz çocuksun

76 Plš şeklinde yazılan sözcük, güçlü tahminlere dayanarak fraš diye okunmuştur. $\mathrm{Bu}$ nedenle sözcüğe Said Oryan "ok", Modi "silah" anlamı vermiş; Âmuzgâr ise Geştaspnâme'ye atıf yaparak "süngü" anlamını tercih etmiştir. Geştaspnâme'nin ilgili pasajında geçen sözcük süngüdür. Bkz: Âmuzgâr, Yâdgâr-i Zerîrân, 32; Oryan, Mutûn-i Pehlevî, 57; Modi, Aiyâdgâr-i-Zarirân, 33; Dakikî, Goştaspname, 221.

771 ve 2 . bentte çoğul haliyle geçen wāspuhr sözcüğü, aslında "şehzade" demektir. Âmuzgâr, Viştasp ile Zerîr'in kardeş olmasından ötürü Bestûr'un bu sözünü yorumlama gereği hissetmiştir. Bkz: Âmuzgâr, Yâdgâr-i Zerîrân, 33. 
ve savaşlarda, [kendini] müdafaa etmeyi bilmezsin! Parmaklarin ok [atacak kadar] dayanıklı değil! 81-Hunlar gelip seni öldürebilir; çünkü onlar Zerîr'i öldürdüler. [Seni öldürdükten] sonra Hunlar <Biz Iran komutanı Zerîr'i öldürdük ve biz onun oğlu Bestûr'u öldürdük> diye iki nam kazanacaklar!"

82-Sonra Bestûr, baş seyise gizlice [şöyle] dedi: "Viştasp Şah, <Çocukken Zerîr'in bindiği atı Bestûr'a verin!> diye emretti." 83-Baş seyis, atın eyerlenmesini emretti ve Bestûr ata bindi. At salınd1 ${ }^{78}$ ve [Bestûr] kahraman babasının öldügünü gördüğü yere varıncaya kadar düşman öldürdü. 84Uzun süre geçmedi ve [şöyle] dedi: "Ey koca ağaç! ${ }^{79}$ Canını kim katledip aldl ${ }^{80}$ Ey cengâver! Gücün ${ }^{81}$ kim senden ald $\imath$ ? Ey Simurg! O süratli atın kim aldı? 85-Her zaman Hunlarla savaşmayl isterdin; şimdi yurtsuz ve kimsesiz bir adam gibi, bizim savaşımızda, nasıl düşürülür, [nasıl] öldürülürsün! 86-Bu örgülü̈2 saçını ve sakalını rüzgâr karıştırmış. Temiz bedenini atlar çiğnemiş. Elbiseni ${ }^{83}$ toprak örtmüş. Şimdi ne yapayım! Eğer attan inersem; senin, babamın başını bir kenara koyarsam, toprağı üstünden alırsam ve sonra tekrar kolayllkla ata binemezsem, 87-Hunlar gelebilirler ve seni öldürdükleri gibi beni de öldürebilirler. Sonra da Hunlar <Biz Iran

78 Metnin tercümesi zor fiillerinden biri "frāz hištan" fiilidir. Frāz, "ön, ileri” anlamındadır ve farklı fiillerin başına gelerek birleşik fiiller oluşturur. Hişten ise "bırakmak, salmak, terk etmek" demektir. Bkz: MacKenzie, A Concise Pahlavi Dictionary, 33, 43. Bu iki sözcük birleşik fiil olarak kullanıldığında sadece "ileri gitmek, salınmak" anlamı vermemekte, cümleye abartı anlamı da katmaktadır.

79 Said Oryan, sözcüğü "dārūg" diye okumuş, diraht/ağaç olarak çevirmiştir. Dārūg diye okunan sözcük, dārū/dār şekliyle "ağaç" demektir. Ancak dārūg/dārōk şekliyle İngilizcedeki drug/deva anlamına gelebilir. Bkz: Oryan, Mutûn-i Pehlevî, 58; MacKenzie, A Concise Pahlavi Dictionary, 24; Nyberg, A Manuel of Pahlavi, 58. Bu nedenle Modi, "Ey ruhumun sevincini artıran kişi! / Oh, increaser of the delight of my soul!" şeklinde bir çeviri yapmıştır. Bkz: Modi, Aiyâdgâr-i-Zarirân, 37.

80 "Aldı" şeklinde çevirdiğimiz sözcük, Partça kökenli amwaštan fiilidir. Bu fiil, "toplamak, almak, bir araya getirmek" gibi anlamlara gelmektedir. Modi, bu sözcüğü silent/suskun olarak çevirmiş̧ir. Bkz: MacKenzie, A Concise Pahlavi Dictionary, 8; Modi, Aiyâdgâr-i-Zarirân, 37.

81 Padrān ya da payrāhan şeklinde anlaş1labilecek sözcük, Oryan tarafindan mukavemet/ direnç; Âmuzgâr tarafından pîrâhen/gömlek anlamında değerlendirilmiştir. Bkz: Âmuzgâr, Yâdgâr-i Zerîrân, 34; Oryan, Mutûn-i Pehlevî, 58.

82 “Örgülü” yerine "derli toplu, düzenli” anlamı da verilebilir. Bkz: Âmuzgâr, Yâdgâr-i Zerîrân, 34.

83 "Elbise" sözcüğü yerine metinde grīw sözcüğü geçmektedir. Bu sözcük hem "gerden, girîbân/boyun, yaka" hem de "nefis, can" anlamına gelmektedir. Bkz: MacKenzie, $A$ Concise Pahlavi Dictionary, 37; Nyberg, A Manuel of Pahlavi, 85. 
komutanı Zerîr'i öldürdük ve biz onun oğlu Bestûr'u öldürdük> diye iki nam kazanirlar."

88-Sonra Bestûr, atını ileri sürdü ve Viştasp Şah'ın önüne varıncaya kadar düşman öldürdü. [Viştasp Şah'1n huzuruna gelince şöyle] dedi: “Gittim; yiğitlerin savaşını ve Viştasp hanedanını olduğu gibi gördüm. 89-Ölüsünü gördüm o cesur komutan, kahraman Zerîr'in, benim babamin. Eğer zatıaliniz beni bırakmayı uygun görürse gideceğim ve babamın intikamını alacă̆ım." 90-Sadrazam Camasp, "Bırakın bu çocuğu! Çünkü kaderi onunla beraberdir; [gidince] düşmanı öldürecektir." dedi. 91-Ve Viştasp Şah, bir atın eyerlenmesini emretti. 92-Bestûr ata bindi. Viştasp Şah, kendi ok kuburundan bir ok verdi; ona dua etti ve [şöyle] dedi: "Şimdi benden bu oku/kuburu [al] ve git! Umulur ki muzaffer olarak gelesin, kendi savaşında ve her savaşta muzaffer olasın, her savaşta nam kazanasın, sonsuza dek düşmanlarının ölüsüyle gelesin! 93-Ve şimdi atlara ve Iran ordusunun sancă̆ına ${ }^{84}$ sen komuta edeceksin! [Umulur ki] ebediyete kadar hatırlanacak bir nam getiresin!"

94-Sonra Bestûr, atıyla hücum etti ve düşman öldürdü. Savaş meydanında öyle kahramandı ki İran komutanı Zerîr gibiydi. 95-Hunların hükümdarı Ercasp, [bulunduğu] dağın tepesinden [Bestûr'un kahramanlığını] gördü ve [şöyle] dedi: "O da kim? O Keyanilerden kahraman bir çocuk ki kahramanlara yakışır bir atı var ve kahramanlara yaklşır bir şekilde eyerini ${ }^{85}$ tutuyor; savaş meydanında, Iran komutanı Zerîr'in savaştığı gibi kahramanca savaşlyor. 96-Bana öyle geliyor ki o kişi Viştasp ailesinden, Zerîr'in intikamını almaya gelen biridir. 97-Siz Hunların içinden, gidecek ve o çocuğu öldürecek kim var? [Kim onu öldürürse] ona, kızım Bisütûn'u eş olarak veririm ki bütün Hun yurdunda ondan daha güzel bir kadın yoktur. 98[Onu öldürecek kişiyi] bütün Hun yurduna sadrazam yapacağım. Çünkü ĕger o çocuk geceye kadar hayatta kalırsa, uzak olmayan bir zamanda, biz Hunlardan hiç kimse să̆ kalmaz!"

99-Sonra Büyücü Bîderefş ayağa kalktı ve "Gitmem için bana bir at eyerleyin!' dedi. 100-Demir toynaklı atı, Zerîr'in atını eyerlediler ve Büyücü

84 Modi, metinde yeterince anlaşılmayan 'yl'nk 'lwm ifadesini Arum olarak okumuştur. $\mathrm{Bu}$ nedenle "Roma ve İran ordumuzun sancağı" şeklinde bir çeviri yapmıştır. Bkz: Modi, Aiyâdgâr-i-Zarirân, 41.

85 Eyer anlamındaki zēn sözcüğü Âmuzgâr tarafından "silah" olarak yorumlanmıştır. Bkz: Âmuzgâr, Yâdgâr-i Zerîrân, 36. 
Bîderefş ata bindi. Şeytanların cehennemde gazap ve zehirle yaptıkları ve günah suyuyla yıkadıkları büyülü mızrağı aldı. [Mızrağı] elinde tuttu ve savaş [meydanına] hücum etti. Bestûr'un nasıl kahramanca savaştı̆̆ını gördü. Doğrudan [Bestûr'un] karşısına çıkamazdı. Arkasından gizlice gitti. 101- Bestûr [onu] gördü ve [şöyle] dedi: "Ey günahkâr büyücü! Önüme gel! Çünkü ben uyluğumun altında bir ata sahibim; ama dört nala koşturmayı bilmiyorum. Ben kuburun içinden bir oka sahibim; ama [ok] atmayı bilmiyorum. Önüme gel ki tatlı canını alayım senin! Tipkı o cesur komutan Zerîr'in, benim babamın [canını aldığın gibi]." 102-Ve Büyücü Bîderefş cesaretlendi; [Bestûr'un] önüne çıtı. Zerîr'in demir toynaklı siyah at1, Bestûr'un sesini duyunca dört ayağını yere vurdu; dokuz yüz doksan dokuz defa ses çıkardı. 103-Bîderefş mızrağını attı ve Bestûr onu, havada eliyle yakaladı. 104-Sonra Zerîr'in ruhu [şöyle] haykırdı: "O [büyülü] mızrağı elinden at! Kuburundan bir ok al ve bu günahkara karşılık ver!" 105Bestûr mızrağı elinden attı ve kuburundan bir ok aldı. Bîderefş'i kalbinden vurdu; [Bîderefş'in] arkasına geçti, onu yere attı ve onun canını aldı ${ }^{86}$

106-Sonra [Bestûr] Zerîr'in o inci bezeli beyaz postalını ve altın [işlemeli] elbisesini aldı; Zerîr'in atına bindi. Kendi atının [dizginini] eline aldı ve [sonra] atı saldı. Camasp'ın oğlu Goramî'nin iki eliyle savaştığı ve zafer sancağını dişleriyle tuttuğu yere varıncaya kadar düşman öldürdü. 107- Goramî ve o büyük ordu, Bestûr'u görünce hep birlikte Zerîr'e yas tuttular ve dediler ki "Senin parmakların ok atacak kadar güçlü değilken ve savaşlarda [kendini nasıl] müdafaa edeceğini bilmezken buraya neden geldin? 108-Hunlar gelebilir ve Zerîr'i öldürdükleri gibi seni de öldürebilirler. Sonra Hunlar < Biz Iran komutan Zerîr'i öldürdük ve biz onun oğlu Bestûr'u öldürdük> diye iki nam kazantrlar!" 109-Bestûr [bunun üstüne şöyle] dedi: "[Umulur ki] zafer kanasın bu zafer sancağını [taşıyarak] Ey Camasp'ın oğlu Goramî! Ĕger sağ olarak Viştasp Şah'ın huzuruna varırsam ona senin savaş meydanında nasıl kahramanca savaştığını söyleyeceğim."

110-Sonra Bestûr atını sürdü. Cesur kahraman İsfendiyar'ın savaştığı yere varıncaya kadar düşman öldürdü. 111-İsfendiyar, Bestûr'u görünce büyük İran ordusunu Bestûr'a bıraktı; kendi başına dağın tepesine gitti ve Ercasp

86 "Ve onun canını aldı." tümcesi, Said Oryan dışındaki mütercimler tarafından 106. bende dahil edilmiştir. 
ile onun yanındaki on iki tümen askere dağın tepesinden saldırdı. Onları [önüne katıp] ovaya indirdi. İsfendiyar'ın kıyımı [onları] Goramî'ye itti. Goramî saldırdı ve [bu saldırı onları] Bestûr'a itti. 112-Uzun bir zaman geçmeden o Hunların içinden, Hun hükümdarı Ercasp dışında kimse sağ kalmadı. 113-Kahraman İsfendiyar [Ercasp'1] yakaladı. Onun [bir] elini, [bir] ayağını ve [bir] kulağını kesti; [bir] gözünü ateşle yaktı. Sonra onu, kuyruğu kesilmiş bir eşeğe bindirip ülkesine gönderdi. 114-[Ona şöyle] dedi: "Git ve [ülkendekilere], benim elimden, Kahraman İsfendiyar'in [elinden] ne gördüysen söyle! [Yoksa] Hunlar, Fravardin ${ }^{87}$ gününde, ejderha takımyıldızına [göre] Vişstasp'ın savaşında ne olduğunu nasıl bilir!"

\section{[Sonsöz]}

1-[Bu anlat1] selamla, mutluluk ve memnuniyetle son buldu. Lohrasp'in oğlu Viştasp ve Zerîr, Bestûr ve İsfendiyar cennetten nasiplerini alalar. Aynı şekilde Viştasp oğlu Fraşavard ve Camasp oğlu Goramî, Pad Hüsrev-i Pad Yasn (?) nam aldılar/alalar! 2-Bütün hanedan, yiğitler, savaşçılar; yüce cennette, mucizevi mekânın sonsuz aydınlığında, hayırlı bir yere erişeler! 3-Her şey çoğala ki ruh sonsuz ola! Kendisi için [bu destanın] yazıldığı koruyucu din, mutlu ve muzaffer ola! Mutlu olanların çocukları, mutlu oğullara sahip olalar! 4-Kıyamet gününe kadar binlerce y1l kutlu ola! Yer ve yurt bayındır ola, her şey bol ola! 5-Ki mutlu olasınız. Eğer [bu] kutlu kitab1 okursanız, Rüstem Mihriban'1 mutlulukla yad edesiniz [ve] bu nüshayı yazmış kişiyi de. Ben, dinin hizmetkarı Mihriban Keyhüsrev [bu nüshayı] yazdım. 6-Bunu okuyan, bizi hayırla yad eden ${ }^{88}$ kişi, bu ferah dünyada sağlık [bula! Ve ölüm vakti] geldiğinde sonsuzluk mekanına [erişe]; [bu destanı] yazmış olan ve dindar evlatlarınızdan olan ben, bu müreffeh ve güzel

87 Âmuzgâr'ın bu husustaki yorumunu ifade etmiştik. Hamaspehmedîm, y1lın son beş günü kutlanan bayramdır. Farvardin ise yılın ilk ayı ve aynı zamanda 19. günüdür. 30 ve 31. bentte geçen "Bir ay boyunca su bulamadılar. Elli gün boyunca aydınlık bir gün görmediler." cümleleri, bu yolculuğun bir aydan uzun sürdüğünü göstermektedir. $\mathrm{Bu}$ gerekçeyle Farvardin ayına denk gelmesi mümkün değildir. Hamaspehmedîm'de, Viştasp'ın sarayına gelen ahaliden kurulan ordu en az 50 günlük bir yola çıkmıştır. Ercasp'a yazılan mektupta savaş için dudīgar $m \bar{a} h /$ gelecek ay uygun görülmüş, ahali dudīgar māh/gelecek ay Viştasp'ın sarayına çağrılmıştır. Bu ifadeler, savaşın günü hususunda metnin tutarlı olmadığı göstermektedir. Bununla birlikte Farvardin ayının değil Farvardin gününün metne daha uygun olacağını ortaya koymaktadır.

88 Ya da "Kim bu kitabı okursa, adımızı hayırla yâd ede!" diye çevrilebilir. Bkz: Âmuzgâr, Yâdgâr-i Zerîrân, 43. 
dünyada en şerir yaratığa karşı muzaffer olayım! ${ }^{89} 7$-Yaratıcı Ohrmazd ve Zerdüşt Spitama [dini] üstüne ibadet edenler muzaffer ola, zafer kazana... [O Zerdüşt ki] Mezdiyesna inanırlarının temiz dinini getiren ve [o dini] dost Viştasp Şah'a, Zerîr'e ve İsfendiyar'a ulaştıran kişidir.

\section{Değerlendirme ve Sonuç}

Goştasp/Key Viştasp Şah'ın Zerdüştîliğe intisabı, İranlıların kullandığı Zodyak takviminin son miladıdır; yani bir kıyamet alametidir. Viştasp'ın Mezdiyesna dinini benimsemesi ile III. çağ kapanmış, IV. çağ/son çağ başlamıştır. Zerdüşt, bir hükümdarın dinini benimsemesi ile önemli bir hami bulmuş ve Zerdüştîlik, Viştasp sayesinde ciddi biçimde yayılmıştır. Bu nedenle Avesta' da Viştasp Yaşt adiyla müstakil bir bölüm bulunmakta; Viştasp'ın Mezdiyesna dinine girmesi anlatılmaktadır. Zerdüştî kaynakların kahir ekseriyeti, Zerdüşst'ten bahsederken Viştasp Şah'1 anmaktadır. Viştasp'ın bu yeni dini kabulü, yeni düşmanlar kazanmasına neden olmuştur. Xiyōn/Hun hükümdarı Ercasp, Keyanîleri, bu dinden dönmeleri için tehdit etmiş; ancak Viştasp'ın "sıkıntıya düştüğü" anda Zerîr, Hunları savaşmaya davet etmiştir. Zerîr, Büyücü Bîderefş tarafından öldürülmüş; fakat savaşı Keyanîler kazanmıştır. Yâdgâr-i Zerîrân; bu savaşı konu edinen, 114 bende ayrılmış 346 satırdan oluşan, Mihrâbân Keyhüsrev'in 691/1322 tarihli nüshası ile günümüze ulaşmış en eski kahramanlık anlatısıdır. Bu anlat1, hudayiname/şehname türü eserlere kaynaklık etmiş; Firdevsî'nin Şehnamesine aldığı Dakikî’nin Geştaspnâmesine ilham vermiştir.

Yâdgâr-i Zerîrân'ın Partça bir metinden Pehleviceye aktarılma ihtimali yüksektir; çünkü hem metinde bazı kopukluklar görülmektedir hem de Geştaspnâme ve Şehname'de görülmeyen tutarsızlıklar söz konusudur. Kopukluğun en çok hissedildiği yer 69 ile 70. bentlerdir. Camasp'ın kehanetinden hemen sonra hükümdarlar dağ başlarına konuşlanmakta ve savaş başlamaktadır. Oysa Geştaspnâme'de savaş başlamadan önce askerlerin atlarına binmeleri ve meydana gelmeleri betimlenmekte, okuyucu savaş sahnesine hazırlanmaktadır. Tutarsızlık ise metindeki zaman ifadelerinde görülür. Zerîr, Ercasp'ı dudīgar māh/gelecek ay savaşmaya çağırır ve sa-

89 Ya da "[Bu destanı] yazan beni ve dindar evlatlarımızı bu dünyada, iyilerin arasında [yad ede!]. En şerli yaratıklara karşı muzaffer ola!” diye çevrilebilir. Bkz: Oryan, Mutûn-i Pehlevî, 63. 
vaşmak için bir yer tarif eder. Ercasp da ülkede yaşayan ahaliyi dudīgar $m \bar{a} h /$ gelecek ay, sarayına asker olarak çağırır. Savaşa katılacak ordunun hazırlanmasina yeter miktarda zaman yokken saraydan hareket eden ordu, 30 ve 31. bentlerden anlaşıldığı kadarıyla en az 50 gün sürecek bir sefere çıkar. Bu zaman ifadeleri tutarsızdır. Âmuzgâr, 26. bentteki müphem ifadeyi "Hamaspehmedîm" diye okuyarak bir çıkış yolu aramış ve 114. bentteki Farvardin gününü, Farvardin ayı olarak yorumlamıştır. Ancak bu girişim de zaman mefhumları arasındaki tutarsızlığı çözmeye yardımcı olmamaktadır. Sözünü ettiğimiz kopukluk ve tutarsızlık, Sasaniler dönemi derleme faaliyetleri ile ilgili değilse anlatının Avestaî kaynaklardan hareketle yazıldığı ve şifahî bilgilere yer verildiği düşünülebilir. Ancak metnin ilk cümlesi, Viştasp Şah dönemine atıf yapmaktadır; yani anlatının ne derece kadim olduğunu bizzat kendisi ifade etmektedir.

Metinde, Camasp'ın Viştasp'tan yemin alması hadisesinde görüldüğü üzere tam olarak anlaşılamayan ve muhtemelen Zerdüştî geleneklerini yansıtan bazı müphem ifadeler yer almaktadır. "Druvasp" sözcüğünün cins isim veya özel isim olarak yorumlandığı görülmektedir. Anlatıdaki Partça sözcükler ayrı bir tartışma alanı açmakta ve mētarag/bulut gibi Yunanca kökenli sözcükler, araştırmacılar tarafından farklı yorumlanmaktadır.

Yâdgâr-i Zerîrân'da 18 şahıs ismi geçmektedir. Bu isimlerden Rüstem, Viştasp'ın kız kardeşi ve karısı Hotes, kızı Humay; Ercasp'ın kızları Zersütûn ve Bisütûn anlatının kahramanları arasında yer almamaktadır. Ayrıca metinde Zerdüşt'e hiç atıf yapılmazken Ohrmazd/Ahura Mazda d1şında Tanrı Azer'den de söz edilmektedir. Eserde somut bir mekân ismi verilmemekte, Iranşehr ve Hun diyarı gibi kapsamlı ifadeler kullanılmaktadir.

\section{Kaynakça}

Âmuzgâr, Jâle. Yâdgâr-i Zerîrân. Tahran: Muîn, 1392.

Ardâvîrâfnâme. Çev. Nimet Y1ldırım. İstanbul: Pinhan Yayıncılık, 2017.

Aro, Jussi. Çev. Esko Naskali. "Zerdüşt Muamması.” Marmara Türkiyat Araştırmaları Dergisi 1, no. 2 (Sonbahar 2014): 197-208.

Athenaeus. The Deipnosophists or Banqued of the Learned of Athenaeus III. Çev. Charles Duke Yonge. Londra: Henry George Bohn, 1954. 
Bahar, Muhammed Taki. "Yâdgâr-i Zerîrân Yâ Şahname-i GoştaspHamase-i Millî-yi İran-i Kadîm.” Mecelle-i Ta'lim ve Terbiyet 5, no. 3 (Hordâd Mâh, 1314): 113-120.

Boyce, Mary. "Zariadres and Zarēr." Bulletin of the School of Oriental and African Studies 17, no. 3 (1955): 463-477.

Boyce, Mary. A History of Zoroastrianism I. Leiden: Brill, 1975.

Dakikî. Goştaspname. Çev. Nimet Yıldırım. İstanbul: Kabalıı Yayıncılık, 2018.

Demirci, Kürşat. Hinduizmin Kutsal Metinleri Vedalar. İstanbul: İşaret Yayınlar1, 1991.

Firdevsî. Şehname I. Çev. Necati Lugal, Kenan Akyüz. Ankara: MEB Yayınları, 1956.

Gutas, Dimitri. Yunanca Düşünce Arapça Kültür. Çev. Lütfü Şimşek. İstanbul: Kitap Yayınevi, 2017.

Hânlerî, Perviz Nâtil. Tarih-i Zeban-i Farsî-I. Tahran, 1365.

Herodotos. Tarih. Çev. Müntekim Ökmen. İstanbul: Türkiye İş Bankası Kültür Yayınları, 2012.

Jamasp-Asana, Jamaspji Minocheherji (ed.). The Pahlavî Text-II. Bombay: Fort Printing Press, 1913.

Jamasp-Asana, Jamaspji Minocheherji (ed.). Corpus of Pahlavi Texts. Bombay, 1913.

Karatay, Osman. Iran ile Turan. Ankara: Karam Yayınları, 2013.

Kent, Roland. Old Persian. New Haven: American Oriental Society, 1950.

MacKenzie, David Neil. A Concise Pahlavi Dictionary. London: Oxford University Press, 1986.

Mâhyâr Nevvabî, Yahya. Yâdgâr-i Zerîrân. Tahran: Esatîr, 1387.

el-Mesudî, Ebü'l-Hasen Alî b. el-Hüseyn b. Alî. Kitabu't-Tenbîh ve'l-İşraf. Leiden: Brill, 1893.

Modi, Jivanji Jamshedji. Aiyâdgâr-i-Zarirân. Bombay: Education Society's Steam Press, 1899. 
Müller, Max, ed., "Dînkerd VII." içinde The Sacred Books of The East. Çev. E.W. West, 3-118. Oxford: The Clarendon Press, 1897.

Müller, Max, ed., "Bundehişn." içinde The Sacred Books of The East. Çev. E.W. West, 1-152. Oxford: The Clarendon Press, 1880.

Nyberg, Henrik Samuel. A Manual of Pahlavi. Tahran: Esâtir, 2003.

Oryan, Said. Mutûn-i Pehlevî. Tahran: Kitâbhâne-i Millî, 1371.

Oryan, Said, ed., Dînkerd IV. Çev. Meryem Rızaî. Tahran: Neşr-i İlmî, 1393.

Peterson, Joseph, ed., Dînkerd III. Çev. Ratanshah E. Kohiyar. 1999.

Peterson, Joseph, ed., Büyük Bundehişn. Çev. Behramgore Tehmuras Anklesaria. Bombay, 1956.

es-Sealibî, Ebû Mansûr Abdülmelik b. Muhammed b. İsmâîl. Ğureru Ahbâri Mülûki'l-Furs ve Siyerihim. Çev. Hermann Zotenberg. Paris, 1900.

Sivrioğlu, Ulaş Töre. Avesta Dili, Grameri ve Etimolojik Sözlüğü. İstanbul: Avesta Yayınları, 2015.

Sivrioğlu, Ulaş Töre. "Pehlevice (Orta Farsça) Bir Tarihî Coğrafya Metni: Šahrestānīhā 1 Ērānšahr." Akademik Tarih ve Düşünce Dergisi 1, no. 3 (Ağustos 2014): 1-27.

Tefazzulî, Ahmed. Târîh-i Edebiyyât-i Îrân Pîş̧ Ez İslam. Tahran: Sohen, 1378.

Yıldırım, Nimet. Fars Mitolojisi Sözlügü. İstanbul: Kabalcı Yayınevi, 2008.

Yıldırım, Nimet. İran Mitolojisi. İstanbul: Pinhan Yayıncılık, 2015.

\section{Internet Kaynakları}

Encyclopædia Iranica. "Kustīg." J. K. Choksy ve F. M. Kotwal. Son erişim: 12 Mart 2019, http://www.iranicaonline.org/articles/kustig 
Ek-1: Yâdgâr-i Zerîrân'ın İlk Sayfası 90

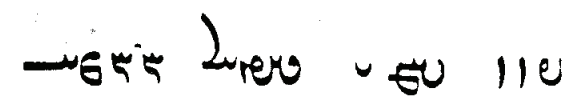

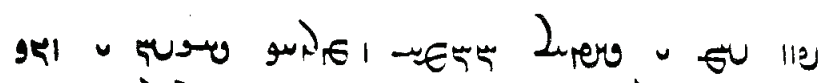

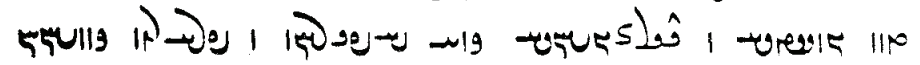
-

1 约

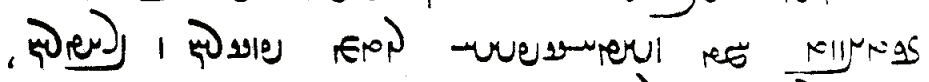

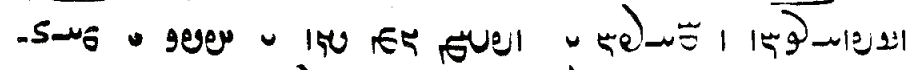

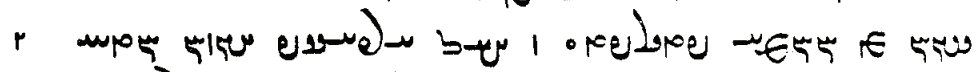
ندs

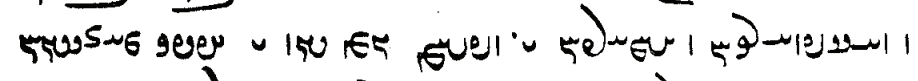

r 6

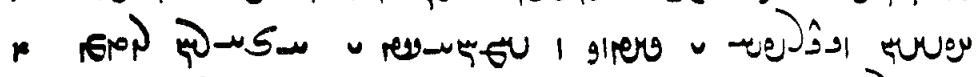
וliers

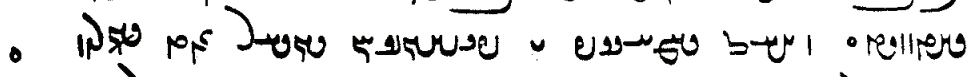
פو עل

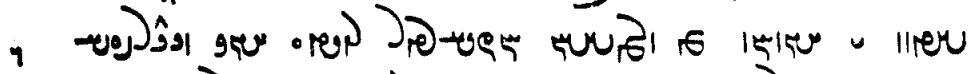

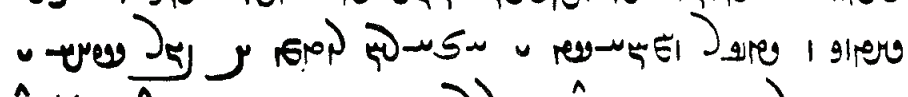
دाأ !

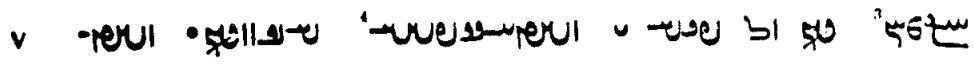

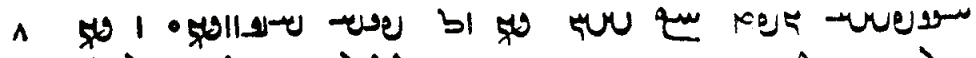

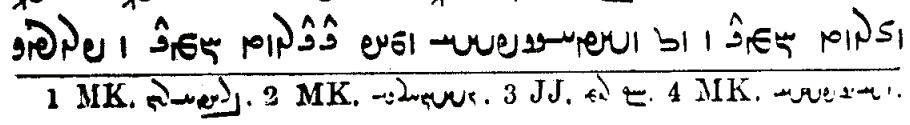

90 Jamasp-Asana (ed.), Corpus of Pahlavi Texts, s.1. 